\title{
Syngas production plus reducing carbon dioxide emission using dry reforming of methane: utilizing low-cost $\mathrm{Ni}$-based catalysts
}

\author{
Saeid Abbasi, Mohsen Abbasi*, Firouz Tabkhi, and Benyamin Akhlaghi \\ Department of Chemical Engineering, Faculty of Petroleum, Gas and Petrochemical Engineering, Persian Gulf University, 75169 \\ Bushehr, Iran
}

Received: 11 July 2019 / Accepted: 5 March 2020

\begin{abstract}
Applicability of using Dry Reforming of Methane (DRM) using low-cost Ni-based catalysts instead of Conventional Steam Reformers (CSR) to producing syngas simultaneously with reducing the emission of carbon dioxide was studied. In order to achieving this goal, a multi-tubular recuperative thermally coupled reactor which consists of two-concentric-tubes has been designed (Thermally Coupled Tri- and Dry Reformer [TCTDR]). By employing parameters of an industrial scale CSR, two proposed configuration (DRM with firedfurnace and Tri-Reforming of Methane (TRM) instead of fired-furnace (TCTDR)) was simulated. A mathematical heterogeneous model was used to simulate proposed reactors and analyses were carried out based on methane conversion, hydrogen yield and molar flow rate of syngas for each reactor. The results displayed methane conversion of DRM with fired-furnace was $35.29 \%$ and $31.44 \%$ for $\mathrm{Ni}-\mathrm{K} / \mathrm{CeO}_{2}-\mathrm{Al}_{2} \mathrm{O}_{3}$ and $\mathrm{Ni} / \mathrm{La}_{2} \mathrm{O}_{3}$ catalysts, respectively, in comparison to $26.5 \%$ in CSR. Methane conversion in TCTDR reached to $16.98 \%$ by $\mathrm{Ni} / \mathrm{La}_{2} \mathrm{O}_{3}$ catalyst and $88.05 \%$ by $\mathrm{NiO}-\mathrm{Mg} / \mathrm{Ce}-\mathrm{ZrO}_{2} / \mathrm{Al}_{2} \mathrm{O}_{3}$ catalyst in TRM side. Also, it was $15.88 \%$ using $\mathrm{Ni}-\mathrm{K} / \mathrm{CeO}_{2}-\mathrm{Al}_{2} \mathrm{O}_{3}$ catalyst in the DRM side and $88.36 \%$ using $\mathrm{NiO}-\mathrm{Mg} / \mathrm{Ce}-\mathrm{ZrO}_{2} / \mathrm{Al}_{2} \mathrm{O}_{3}$ catalyst in TRM side of TCTDR. Finally, the effect of different amounts of supplying energy on the performance of DRM with fired-furnace was studied, and positive results in reducing the energy consumption were observed.
\end{abstract}

\section{Introduction}

Hydrogen is a main raw material for chemical industries such as oil refining industries, production of ammonia, dimethyl ether, methanol, or aniline [1-4]. Also, it has potential in producing and transporting electricity due to its beneficial characteristics such as sustainability, renewability, high energy content, easiness in storage and transportation, high efficiency (particularly in fuel cells), and environmentally friendly [4-6]. In addition to hydrogen, synthesis gas (a mixture of fuel gas) which is comprising of hydrogen and carbon monoxide has a crucial role as an intermediate in industries. Syngases could be used to produce several chemicals and fuels like methanol, Fischer-Tropsch fuels, ethanol, and dimethyl ether [7-12]. Synthesis gas (syngas) is produced from various feedstocks such as coal, petroleum coke, biomass, and natural gas, the efficient commercial production of syngas has gained global regard in the last decades [10-14]. The two major operational problems in syngas production from natural gas are procuring the desired syngas quality $\left(\mathrm{H}_{2} / \mathrm{CO}\right.$ ratio $)$ and

\footnotetext{
* Corresponding author: m.abbasi@pgu.ac.ir
}

preventing coke formation. The desired quality of syngas depends on the purposed application for the syngas $[15,16]$. One of the basic and low-cost procedures to produce syngas with desired quality is the reforming of natural gas [10]. There are four reforming processes; Steam Reforming of Methane (SRM), Dry Reforming of Methane (DRM), Partial Oxidation of Methane (POM), and Tri-Reforming of Methane (TRM) [10].

Natural gas is known as the cleanest fossil fuel, and although methane steam reforming is a traditional, and most prevalent procedure for the production of syngas, but high energy consumption in the low-performance fired-furnace and high $\mathrm{H}_{2} / \mathrm{CO}$ ratio are drawbacks of steam reforming $[9,13,17]$. On the other hand, all of the processes widely utilize fossil fuels and produce a large quantity of $\mathrm{CO}_{2}$ around the world, which causes negative effects on the environment such as global warming, climate change, and ocean acidification [1]. It is predictable that, if various industries utilize the fossil resources without any considerable decreasing in consumption, then $\mathrm{CO}_{2}$ separating must be used to reduce the atmospheric $\mathrm{CO}_{2}$ levels to stop more deterioration on the environment [1]. Consequently, $\mathrm{CO}_{2}$ conversion and consumption have acquired notable 
consideration universally not only due to its negative effect on the global climate, but on sustainable development, $\mathrm{CO}_{2}$ can be utilized as an important carbon source for chemical, oil, and food industries [17-19]. Carbon dioxide is mostly produced by separating from industrial process waste streams in order to reach pure amounts of $\mathrm{CO}_{2}$ [18]. Whereas the separation of carbon dioxide from other compounds in the waste streams consumes an enormous amount of energy and subsequently will be costly, if pure $\mathrm{CO}_{2}$ doesn't be needed, $\mathrm{CO}_{2}$ converting in concentrated sources without separation of $\mathrm{CO}_{2}$ is favored [17, 18]. Flue gases that are produced from fired electric power plants (coal and/or natural gas-fired) are concentrated sources of carbon dioxide that consist of $\mathrm{CO}_{2}, \mathrm{H}_{2} \mathrm{O}, \mathrm{O}_{2}$, and $\mathrm{N}_{2}$ could be a suitable feed for new processes like tri-reforming [17]. Tri-reforming and dry reforming have been suggested by some researchers as an effective procedure for reutilizing $\mathrm{CO}_{2}$ without pre-purification [17, 18].

The dry reforming of methane has gained significant attention recently because of two major reasons: (1) this process consumes waste $\mathrm{CO}_{2}$ and $\mathrm{CH}_{4}$ (greenhouse gases) to produce syngas, (2) this process produces syngas with an appropriate $\mathrm{H}_{2} / \mathrm{CO}$ ratio for DME (dimethyl ether) and Fischer-Tropsch synthesis products [10, 13, 20]. Since dry reforming lonely is not applicable commercially; therefore, combined dry and tri-reforming processes have been proposed as an environment-friendly and efficient procedure for utilization of $\mathrm{CO}_{2}$ and production of syngas. Dry reforming of methane is a procedure that converts $\mathrm{CH}_{4}$ and $\mathrm{CO}_{2}$ to worthful products as $\mathrm{CO}$ and $\mathrm{H}_{2}$ that are named synthesis gas [17, 21-23]. These below reactions occur during DRM:

$$
\mathrm{CH}_{4}+\mathrm{CO}_{2} \leftrightharpoons 2 \mathrm{CO}+2 \mathrm{H}_{2} \quad \Delta \mathrm{H}^{\circ}=247.3 \mathrm{~kJ} / \mathrm{mol} .
$$

Reverse water gas shift is a significant side reaction:

$$
\mathrm{CO}_{2}+\mathrm{H}_{2} \leftrightharpoons \mathrm{CO}+\mathrm{H}_{2} \mathrm{O} \quad \Delta \mathrm{H}^{\circ}=-41.1 \mathrm{~kJ} / \mathrm{mol} \text {. }
$$

One of the main drawbacks of DRM is coke formation on the active surface of catalysts that cause catalyst deactivation rapidly. Carbon deposition depends on parameters such as: temperature, catalyst type, and the existence of oxygen and steam in the process, though, and carbon deposition could be significantly eliminated by adjusting parameters and using an adequate catalyst [17, 24].

Tri-reforming of methane has been designed in order to produce syngas which combines steam reforming of methane, carbon dioxide reforming of methane, and oxidation of methane in a single reactor. The following reactions occur during TRM $[4,10,15,25]$ :

Steam Reforming of Methane (SRM):

$$
\begin{gathered}
\mathrm{CH}_{4}+\mathrm{H}_{2} \mathrm{O} \leftrightharpoons \mathrm{CO}+3 \mathrm{H}_{2} \quad \Delta \mathrm{H}^{\circ}=206.3 \mathrm{~kJ} / \mathrm{mol}, \\
\mathrm{CH}_{4}+2 \mathrm{H}_{2} \mathrm{O} \leftrightharpoons \mathrm{CO}_{2}+4 \mathrm{H}_{2} \quad \Delta \mathrm{H}^{\circ}=164.9 \mathrm{~kJ} / \mathrm{mol} .
\end{gathered}
$$

The Carbon dioxide Reforming (CDR) of methane:

$$
\mathrm{CH}_{4}+\mathrm{CO}_{2} \leftrightharpoons 2 \mathrm{CO}+2 \mathrm{H}_{2} \quad \Delta \mathrm{H}^{\circ}=247.3 \mathrm{~kJ} / \mathrm{mol} .
$$

Partial Oxidation of Methane (POM):

$$
\mathrm{CH}_{4}+\frac{1}{2} \mathrm{O}_{2} \leftrightharpoons \mathrm{CO}+2 \mathrm{H}_{2} \quad \Delta \mathrm{H}^{\circ}=-35.6 \mathrm{~kJ} / \mathrm{mol} \text {. }
$$

Complete Oxidation of Methane (COM):

$$
\mathrm{CH}_{4}+2 \mathrm{O}_{2} \leftrightharpoons \mathrm{CO}_{2}+2 \mathrm{H}_{2} \mathrm{O} \quad \Delta \mathrm{H}^{\circ}=-880 \mathrm{~kJ} / \mathrm{mol} \text {. }
$$

Water-Gas Shift Reaction (WGSR):

$$
\mathrm{CO}+\mathrm{H}_{2} \mathrm{O} \leftrightharpoons \mathrm{CO}_{2}+\mathrm{H}_{2} \quad \Delta \mathrm{H}^{\circ}=41.1 \mathrm{~kJ} / \mathrm{mol} .
$$

Water-Gas Shift Reaction (WGSR) is one of the leading chemical reactions which taking place in the TRM and has a substantial impact during the whole process $[10,26]$. In the reaction system the existence of oxygen and steam help avoid the carbon deposition on the catalyst surface, and also the molar $\mathrm{H}_{2} / \mathrm{CO}$ ratio in the TRM can be controlled better to reach the desired ratio. Also, besides the TRM process integrates endothermic reactions and exothermic reactions [15]. The presence of methane complete and partial oxidation reactions in the tri-reforming process causes to generate a huge amount of heat that is high as it could be utilized for endothermic processes $[6,10,17$, 27]. Syngas produced by the TRM process has the molar $\mathrm{H}_{2} / \mathrm{CO}$ ratio of about 1.5-2, which is appropriate for producing chemical products, for instance: dimethyl ether, methanol, and also liquid hydrocarbons [6, 10, 17, 27].

As mentioned above, the combination of TRM and DRM processes is an effective and economical method in order to produce syngas and also decrease greenhouse gas emission. The purpose of thermally coupled reactors modeling is finding an acceptable solution to eliminate huge fired furnaces and save energy [6]. In general, in thermally coupled reactors, the exothermic reactions as a heat source are coupled with endothermic reactions in a single reactor [10]. Therefore, some extent of generated heat from the exothermic reaction is transferred to the other side of the TCTDR to drive endothermic reaction [10]. Thermally coupled reactors are categorized into three main groups; direct, regenerative, and recuperative coupling [8]. A large number of researchers have studied recuperative coupling in recent years $[6,10,28,29]$. Recuperative coupling reactors configuration consists of two vertical fixed-bed concentric tubes, which are separated by a wall $[6,10,17,30]$. Commonly, the generated heat by the exothermic reaction in the inner tube side is transferred across the tube surface to provide the required heat for endothermic reaction in the outer tube side. Therefore, either of reactions are proceeded simultaneously $[6,10,17,30]$.

The novelty of current study in comparison to our previous research [10] is replacing expensive Rh-based catalysts in DRM side that causes application of these catalysts practically unusable in industries [31-33] with low-cost Ni-based catalysts due to wide availability of $\mathrm{Ni}$ metal which are modified by active metals and have been applied in industries $[6,10]$. Also, in this research in comparison to previous research, two proposed configuration was simulated including utilizing of fired-furnace for DRM and employing TRM for heat supplying and effect of different 


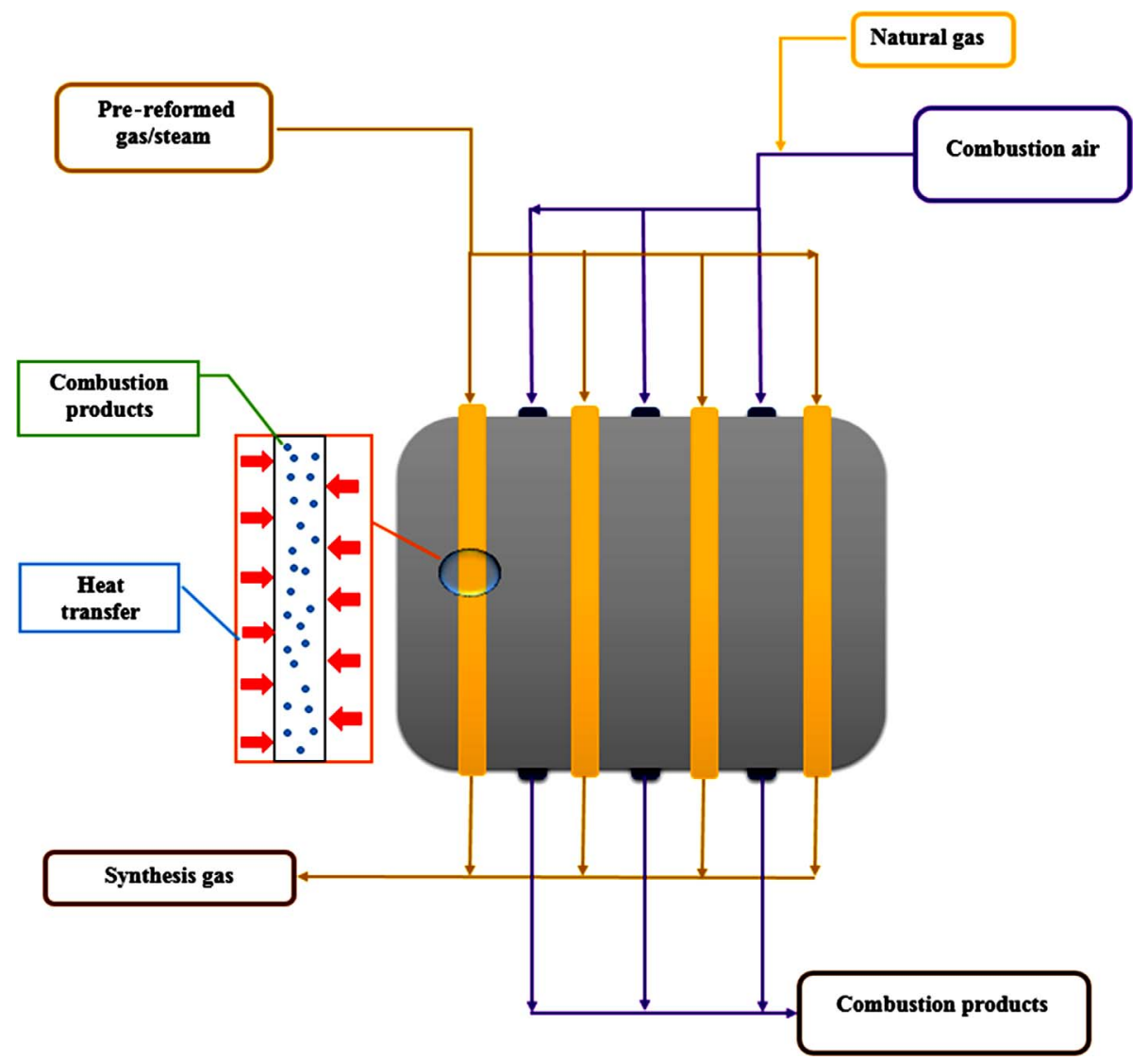

Fig. 1. Schematic of Conventional Steam Reformer (CSR).

amount of supplying energy on performance of DRM process with fired-furnace was studied.

\section{Process description}

\subsection{Conventional Steam Reformer (CSR)}

A scheme of the CSR is displayed in Figure 1. This reactor produces syngas in order to compose methanol in Zagros Petrochemical Company, Assaluyeh, Iran [6, 10]. The conventional steam reformer has been composed of a fixed bed reactor that steam reforming reaction is conducted along the tubular reactor and an enormous fired-furnace (69 MWth) for supplying the required energy to drive steam reforming reaction $[6,10,13]$.

As shown in Figure 1, the pre-reformed gas after being preheated is directed to the steam reformer to be more converted into $\mathrm{CO}, \mathrm{CO}_{2}$, and $\mathrm{H}_{2}$ at Lurgi design. In the CSR, the generated heat by methane combustion in a huge top fired rectangular furnace (with carbon dioxide generation and high energy consumption) is transferred to supply a uniform heat flux for the required heat in endothermic reaction. The steam reforming procedure includes two successive reactions: SRM (Eq. (3)) and WGS (Eq. (8)), [10]. The methane oxidization with steam (steam reforming reaction $)$ is extremely endothermic $\left(\Delta \mathrm{H}^{\circ}=206.3 \mathrm{~kJ} / \mathrm{mol}\right.$ at $25{ }^{\circ} \mathrm{C}$ ), and the needed heat is supplied utilizing the reformer furnace. Then, $\mathrm{CO}$ is oxidized into $\mathrm{CO}_{2}$ entirely during the Water-Gas Shift (WGS) reaction [34]. The outlet stream of CSR, which comprises syngas, is directed to the Conventional Auto-thermal Reformer (CAR) to achieve the complete conversion of methane and desired $\mathrm{H}_{2} / \mathrm{CO}$ ratio for methanol production $[6,10]$. The vertical tubes are filled with Ni-based catalysts [6, 10].

Operational conditions, reactor and catalyst characteristics, and CSR feed composition have been listed in Table 1, $[6,10]$.

\subsection{Dry Reforming of Methane (DRM) with fired-furnace supplying energy}

Dry Reforming of Methane (DRM) is another procedure for syngas production. As mentioned before, the main advantage of DRM is producing syngas by consuming $\mathrm{CO}_{2}$ as a greenhouse gas. Moreover, the molar $\mathrm{H}_{2} / \mathrm{CO}$ ratio of syngas is close to 1, which is suitable for DME and Fischer-Tropsch synthesis products [10]. The dry reforming process consists of DRM as the main reaction (Eq. (1)), and meanwhile, the successive reverse WGS as the side reaction (Eq. (2)) generates water and CO [34]. DRM is highly endothermic and is favorable at high temperature and low pressure [13]. Under stoichiometric conditions and high temperature (above $1300 \mathrm{~K}$ ), methane decomposition 
Table 1. Operational conditions of industrial-scale CSR.

\begin{tabular}{lc}
\hline Parameter & Value \\
\hline Carbon dioxide composition in feed $(\mathrm{mol} / \mathrm{mol})$ & 1.72 \\
Carbon monoxide composition in feed $(\mathrm{mol} / \mathrm{mol})$ & 0.02 \\
Hydrogen composition in feed $(\mathrm{mol} / \mathrm{mol})$ & 5.89 \\
Methane composition in feed $(\mathrm{mol} / \mathrm{mol})$ & 32.59 \\
Nitrogen composition in feed $(\mathrm{mol} / \mathrm{mol})$ & 1.52 \\
Water $($ steam) composition in feed $(\mathrm{mol} / \mathrm{mol})$ & 58.26 \\
Inlet feed temperature $\left({ }^{\circ} \mathrm{C}\right)$ & 520 \\
Inlet feed pressure $(\mathrm{kPa})$ & 4000 \\
Total feed gas flow $(\mathrm{kmol} / \mathrm{h})$ & 9129.6 \\
Tubes number & 184 \\
Diameter of tube inside $(\mathrm{mm})$ & 125 \\
Length $(\mathrm{m})$ & 12 \\
Total filled volume of catalyst $\left(\mathrm{m}^{-3}\right)$ & 27.8 \\
Design pressure $(\mathrm{kPa})$ for tubes & 4100 \\
Design temperature $\left({ }^{\circ} \mathrm{C}\right)$ for tubes & 790 \\
Shape of catalyst & $10-\mathrm{HOLE}$ rings \\
Size of particle $(\mathrm{mm})$ & $19 \times 16$ \\
Void fraction $(-)$ & 0.4 \\
Tube heat load $\left(100 \%\right.$ design case) $\left(\mathrm{kcal} \mathrm{m}^{-2} \mathrm{~h}^{-1}\right)($ according to tube ID) & 68,730 \\
Reformer net duty $\left(100 \%\right.$ design case) $\left(\mathrm{GJ} \mathrm{h}^{-1}\right)$ & 248.2 \\
\hline
\end{tabular}

(Eq. (9)) and carbon deposition (Boudouard reaction, Eq. (10)) occur that cause to coke formation and catalyst deactivation $[13,34]$.

Methane decomposition:

$$
\mathrm{CH}_{4} \leftrightharpoons \mathrm{C}+2 \mathrm{H}_{2} \quad \Delta \mathrm{H}^{\circ}=74.9 \mathrm{~kJ} / \mathrm{mol}
$$

Boudouard:

$$
2 \mathrm{CO} \leftrightharpoons \mathrm{CO}_{2}+\mathrm{C} \quad \Delta \mathrm{H}^{\circ}=-172.2 \mathrm{~kJ} / \mathrm{mol} .
$$

For studying the first configuration that fired-furnace is employed to supplying energy of DRM, DRM replaced with SRM in tubes of industrial-scale CSR that presented in Figure 1 and Table 1. Therefore, operational conditions, reactor, and catalyst characteristics of DRM with firedfurnace supplying energy plus feed composition have been listed in Table 2, [6].

\subsection{Thermally Coupled Tri- and Dry Reformer (TCTDR)}

Figure 2 represents a schematic of Thermally Coupled Tri-reforming and DRM Reactor (TCTDR) that TRM provides heat instead of fired-furnace. According to this figure, a multi-tubular reactor consists of 184 two-concentric-tubes with $12 \mathrm{~m}$ length, has been proposed for the second configuration [10]. The reactor beds are filled with Ni-based catalysts. As it shown from the tube magnification, the endothermic DRM takes place in the inner side of the tube while the tri-reforming process happens in the outer side of the tube. Tri-reforming reaction generates required energy in order to proceed its endothermic reactions of dry DRM in the inner tube side [10, 17]. The Tri-Reforming of Methane (TRM) is an efficient combination of steam reforming, dry reforming, and oxidation of methane in a single reactor to produce useful syngas with adequate molar $\mathrm{H}_{2} / \mathrm{CO}$ ratio for producing chemical products for example dimethyl ether, methanol, and also liquid hydrocarbons $[10,34]$. Furthermore, the TRM process eliminates coke deposition because of the existence of oxygen and hydrogen $[6,10,34,35]$. In addition to the reactions as mentioned above (Eqs. (1)-(10)), other reactions which occur during TRM are described as following [34]:

$$
\begin{array}{r}
\mathrm{C}+\mathrm{H}_{2} \mathrm{O} \leftrightharpoons \mathrm{CO}+\mathrm{H}_{2} \quad \Delta \mathrm{H}^{\circ}=131.4 \mathrm{~kJ} / \mathrm{mol}, \\
\mathrm{C}+\mathrm{O}_{2} \leftrightharpoons \mathrm{CO}_{2} \quad \Delta \mathrm{H}^{\circ}=-393.7 \mathrm{~kJ} / \mathrm{mol} .
\end{array}
$$

In must be noted that the DRM reaction takes place in the inner tube side that the vertical tubes of the reactor have been loaded with $\mathrm{Ni} / \mathrm{La}_{2} \mathrm{O}_{3}$ or $\mathrm{Ni}-\mathrm{K} / \mathrm{CeO}_{2}-\mathrm{Al}_{2} \mathrm{O}_{3}$ catalysts (Fig. 1). All specifications and characterizations of the DRM side in TCTDR configuration are similar to Table 2.

In the TRM side, at first, in order to prepare the feed stream, the pre-reformed gas stream is blended with the stream of natural gas and adjusts the ratio of steam, carbon dioxide, and oxygen $[6,10,17]$. Then the blended stream is directed across the tri-reforming side, which is filled in by $\mathrm{NiO}-\mathrm{Mg} / \mathrm{Ce}-\mathrm{ZrO}_{2} / \mathrm{Al}_{2} \mathrm{O}_{3}$ catalysts pellets. The sizes of the catalysts are the same as the CSR $[6,10,17]$. This catalyst significantly reduces carbon deposition on the reactor 
Table 2. Operating conditions of Dry Reforming of Methane (DRM) with fired-furnace supplying energy.

\begin{tabular}{lc}
\hline Parameter & Value \\
\hline Carbon dioxide composition in feed $(\mathrm{mol} / \mathrm{mol})$ & 49.8 \\
Carbon monoxide composition in feed $(\mathrm{mol} / \mathrm{mol})$ & 0.1 \\
Hydrogen composition in feed $(\mathrm{mol} / \mathrm{mol})$ & 0.1 \\
Methane composition in feed $(\mathrm{mol} / \mathrm{mol})$ & 49.8 \\
Nitrogen composition in feed $(\mathrm{mol} / \mathrm{mol})$ & 0.1 \\
Water $($ steam $)$ composition in feed $(\mathrm{mol} / \mathrm{mol})$ & 0.1 \\
Inlet temperature $\left({ }^{\circ} \mathrm{C}\right)$ & 657 \\
Inlet pressure $(\mathrm{kPa})$ & 4000 \\
Total feed gas flow $(\mathrm{kmol} / \mathrm{h})$ & 9129.6 \\
Tubes number & 184 \\
Diameter of inside $(\mathrm{mm})$ & 125 \\
Length (m) & 12 \\
Total filled volume of catalyst $\left(\mathrm{m}^{-3}\right)$ & 27.8 \\
Design pressure for tubes $(\mathrm{kPa})$ & 4100 \\
Design temperature for tubes $\left({ }^{\circ} \mathrm{C}\right)$ & 790 \\
Particle size $(\mathrm{mm})$ & 0.4 \\
Void fraction $(-)$ & 0.4 \\
Tube heat load $(100 \%$ design case $)\left(\mathrm{kcal} \mathrm{m}^{-2} \mathrm{~h}^{-1}\right)($ according to tube ID) & 68,730 \\
Reformer net duty $\left(100 \%\right.$ design case $\left(\mathrm{GJ} \mathrm{h}^{-1}\right)$ & 248.2 \\
\hline
\end{tabular}

wall and catalyst surface and also, $\mathrm{NiO}-\mathrm{Mg} / \mathrm{Ce}-\mathrm{ZrO}_{2} /$ $\mathrm{Al}_{2} \mathrm{O}_{3}$ catalyst improves the water resistance $[6,10,17]$. The $\mathrm{Ce}-\mathrm{ZrO}_{2}$ and $\mathrm{Mg}$ additives in the catalysts create the basic site and moreover, weak acidic site as well as red-ox ability $[6,15,17]$. The optimized inlet parameters that have been considered for the tri-reformer reactor are listed in Table 3, [10]. Also, Table 4 presents the simulation conditions of the TRM side in TCTDR configuration $[15,17,36]$. According to Tables $2-4$, in addition to using proper Ni-based catalyst, appropriate values of parameters such as temperature, steam to carbon ratio, and oxygen to carbon ratio have been applied in order to eliminate coke formation on the surface of catalysts and the reactor wall $[17,36]$.

\section{Kinetic of reactions}

\subsection{Dry reforming of methane side reactions}

The kinetic rate equation for DRM (Eq. (1)) over Ni/La $\mathrm{O}_{3}$ catalyst in temperature range of $650-750{ }^{\circ} \mathrm{C}$ based on Tsipouriari model, is described by following equations [37]:

$$
\begin{aligned}
r_{\mathrm{CH}_{4}} & =\frac{K_{1} k_{2} K_{3} k_{4} p_{\mathrm{CH}_{4}} p_{\mathrm{CO}_{2}}}{K_{1} k_{2} K_{3} k_{4} p_{\mathrm{CH}_{4}} p_{\mathrm{CO}_{2}}+K_{1} k_{2} p_{\mathrm{CH}_{4}}+K_{3} k_{4} p_{\mathrm{CH}_{4}} p_{\mathrm{CO}_{2}}}, \\
K_{1} k_{2} & =2.61 \times 10^{-3} \exp \left(\frac{-4300}{T}\right) \quad\left[\left(\frac{\mathrm{mol}}{\mathrm{gs}}\right)(\mathrm{kPa})^{-1}\right],
\end{aligned}
$$

$$
\begin{gathered}
K_{3}=5.17 \times 10^{-5} \exp \left(\frac{8700}{T}\right) \quad\left[\mathrm{kPa}^{-1}\right], \\
k_{4}=5.35 \times 10^{-1} \exp \left(\frac{-7500}{T}\right) .
\end{gathered}
$$

Kinetic of reaction for $\operatorname{DRM}$ (Eq. (1)) over $\mathrm{Ni}-\mathrm{K} /$ $\mathrm{CeO}_{2}-\mathrm{Al}_{2} \mathrm{O}_{3}$ catalyst in temperature range of $873-1073 \mathrm{~K}$ $\left(560-800{ }^{\circ} \mathrm{C}\right)$ is considered based on Nandini et al. as follows [38]:

$$
r_{\mathrm{CH}_{4}}=\frac{k_{1 L} p_{\mathrm{CH}_{4}}}{\left[\left(\frac{k_{1 L} p_{\mathrm{CH}_{4}} p_{\mathrm{CO}}}{K_{7 L} K_{a} p_{\mathrm{CO}}}\right)+\left(\frac{K_{b} p_{\mathrm{CO}_{2}} p_{\mathrm{H}_{2}}^{0.5}}{p_{\mathrm{CO}}}\right)+\left(\frac{k_{1 L} p_{\mathrm{CH}_{4}}}{K_{7 L}}\right)+1\right]},
$$

$$
\begin{aligned}
& k_{1 L}=1292 \pm 465 \exp \left(\frac{-12,894 \pm 366}{T}\right) \\
& {\left[\mathrm{g} \cdot \mathrm{mol} / \mathrm{g}_{\text {cat }} \cdot \mathrm{s} \cdot \mathrm{atm}\right] \text {, }} \\
& k_{7 L}=(3.8 \pm 0.1) e^{-3} \exp \left(\frac{-220 \pm 25}{T}\right) \quad\left[\mathrm{g} \cdot \mathrm{mol} / \mathrm{g}_{\text {cat }} \cdot \mathrm{s}\right]
\end{aligned}
$$

$$
K_{a}=(7.4 \pm 4.4) \exp \left(\frac{-4145 \pm 663}{T}\right) \quad\left[\mathrm{atm}^{-2}\right]
$$




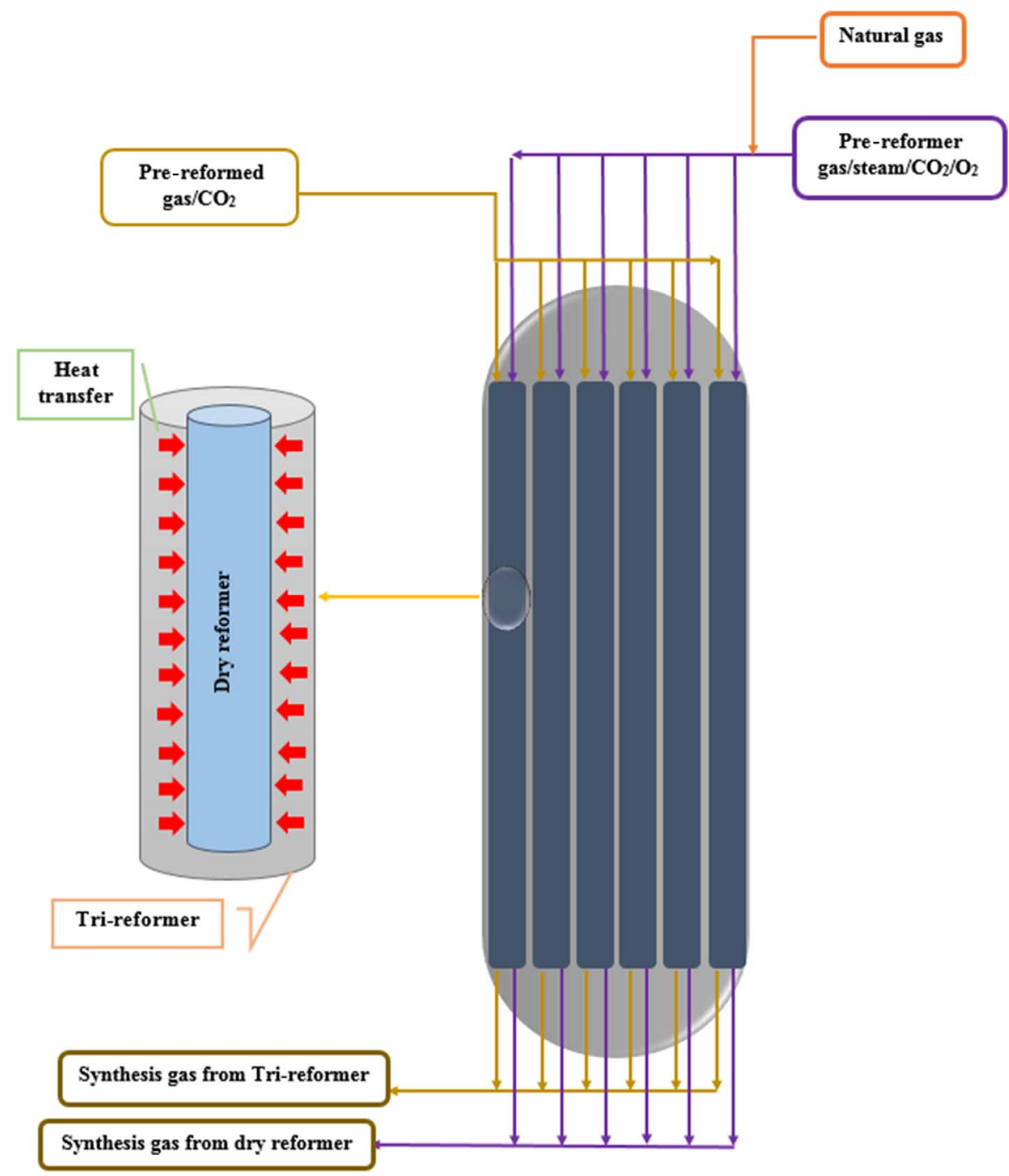

Fig. 2. Schematic of Thermally Coupled Tri- and Dry Reformer (TCTDR) configuration.

Table 3. Optimized parameters for the TRM side of TCTDR.

\begin{tabular}{lc}
\hline Parameter & Value \\
\hline Inlet temperature $(\mathrm{K})$ & 1100 \\
Composition of feed $(\mathrm{mol} / \mathrm{mol})$ & \\
Carbon dioxide & 24.81 \\
Carbon monoxide & 0.01 \\
Hydrogen & 1.53 \\
Methane & 18.7 \\
Oxygen & 8.78 \\
Nitrogen & 0.01 \\
Water (steam) & 46.18 \\
Or reactant ratios & \\
Steam/methane ratio & 2.46 \\
Oxygen/methane ratio & 0.47 \\
Carbon dioxide/methane ratio & 1.30 \\
\hline
\end{tabular}

Table 4. Simulation conditions for the TRM side of TCTDR.

\begin{tabular}{lc}
\hline Parameter & Value \\
\hline Total feed gas flow $(\mathrm{kmol} / \mathrm{h})$ & $28,115.4$ \\
Methane feed rate $(\mathrm{kmol} / \mathrm{h})$ & 9264.4 \\
Inlet pressure $(\mathrm{kPa})$ & 2000 \\
Shape of catalyst & 10-HOLE rings \\
Size of particle $(\mathrm{mm})$ & $19 \times 16$ \\
Shell inner diameter $(\mathrm{m})$ & 2 \\
\hline & \\
$K_{b}=(2.3) e^{7} \exp \left(\frac{-15,998 \pm 2808}{T}\right)$ & {$\left[\mathrm{atm}^{-2.5}\right], \quad(21)$} \\
$c=5.8 \exp \left(\frac{8605}{T}\right)$.
\end{tabular}


Table 5. Arrhenius kinetic parameters, reaction and adsorption equilibrium constants for DRM and RWGS reactions.

\begin{tabular}{lcc}
\hline & DRM & RWGS \\
\hline Rate constant of reaction (mol/gcat s) & $k_{\mathrm{DR}}=1290 \exp \left[\frac{-102.065}{\mathrm{RT}}\right]$ & $k_{\mathrm{RWGS}}=1.856 \times 10^{-5} \exp \left[\frac{-73,105}{\mathrm{RT}}\right]$ \\
Equilibrium constants of reaction & $k_{\mathrm{DR}}=\exp \left[\frac{-(42-0.3(T-773))}{\mathrm{RT}}\right]$ & $k_{\mathrm{RWGS}}=\exp \left[\frac{4400}{T}-4.036\right]$ \\
Equilibrium constants of adsorption $(1 / \mathrm{Pa})$ & $k_{\mathrm{CO}_{2}}=2.64 \times 10^{-3} \exp \left[\frac{37,641}{\mathrm{RT}}\right]$ & $k_{\mathrm{CO}_{2}}=5.6955 \times 10^{-6}\left[\frac{9262}{\mathrm{RT}}\right]$ \\
& $k_{\mathrm{CH}_{4}}=2.63 \times 10^{-3} \exp \left[\frac{40,684}{\mathrm{RT}}\right]$ & $k_{\mathrm{H}_{2}}=1.4705 \times 10^{-5} \exp \left[\frac{6025}{\mathrm{RT}}\right]$ \\
\hline
\end{tabular}

If partial pressure of $\mathrm{CO}_{2}$ be more than $75.99375 \mathrm{kPa}$ $(0.75 \mathrm{~atm})$, the following equation is applied:

$$
r_{\mathrm{CH}_{4}}=c k_{1 L} p_{\mathrm{CH}_{4}} \text {. }
$$

The Reverse Water-Gas Shift (RWGS) reaction also occurs during the synthesis gas production by $\mathrm{CO}_{2}$ reforming. Kinetic of RWGS reaction (Eq. (2)) is expressed as below [39]:

$$
r_{\mathrm{RWGS}}=\frac{k_{\mathrm{RWGS}} K_{\mathrm{CO}_{2}} K_{\mathrm{H}_{2}} p_{\mathrm{CO}_{2}} p_{\mathrm{H}_{2}}}{\left(1+K_{\mathrm{CO}_{2}} p_{\mathrm{CO}_{2}}+K_{\mathrm{H}_{2}} p_{\mathrm{H}_{2}}\right)}\left[1-\frac{\left(p_{\mathrm{CO}} p_{\mathrm{H}_{2} \mathrm{O}}\right)^{2}}{K_{\mathrm{RWGS}} p_{\mathrm{CO}_{2}} p_{\mathrm{H}_{2}}}\right] .
$$

The Arrhenius kinetic parameters, reaction equilibrium constants and constants of adsorption equilibrium are tabulated in Table 5.

\subsection{Tri-reforming side reaction}

In general, kinetic studies are carried out to ascertain the most proper reaction rate model, which is basically deduced from mechanistic reaction pathways for capturing the rates of the experimental reactant reaction and the product formation with the highest accuracy [40].

Equations (3)-(5), and complete methane oxidation (Eq. (7)) have been proposed to explain the tri-reforming process [10]. During tri-reforming reactions, dry DRM (Eq. (1)) is assumed as a dependent reaction since it could be considered as the SRM reaction minus WGS reaction $[6,10,17]$. Thus, consideration of the kinetic model for equations (3) and (5) as a set of independent reactions is sufficient, and there isn't any need to use the kinetic model for DRM reaction (Eq. (1)) [10, 17]. The Xu and Froment kinetic model, which has been derived over Ni-based catalysts is applied for equations (3)-(5) (SRM reactions) $[6,10]$. This kinetic model has been widely investigated under the lab-scale and also is more common in the case of steam reforming reactions [10]. The $\mathrm{Xu}$ and Froment model for the reactions (3)-(5) is described by the following equations $[10,41,42]$ :

$$
R_{1}=\frac{k_{1}}{p_{\mathrm{H}_{2}}^{2.5}}\left(p_{\mathrm{CH}_{4}} p_{\mathrm{H}_{2} \mathrm{O}}-\frac{p_{\mathrm{H}_{2}}^{3} p_{\mathrm{CO}}}{K_{\mathrm{I}}}\right) \times \frac{1}{\varphi^{2}},
$$

$$
\begin{gathered}
R_{2}=\frac{k_{2}}{p_{\mathrm{H}_{2}}^{3.5}}\left(p_{\mathrm{CH}_{4}} p_{\mathrm{H}_{2} \mathrm{O}}^{2}-\frac{p_{\mathrm{H}_{2}}^{4} p_{\mathrm{CO}_{2}}}{K_{\mathrm{II}}}\right) \times \frac{1}{\varphi^{2}}, \\
R_{3}=\frac{k_{3}}{p_{\mathrm{H}_{2}}}\left(p_{\mathrm{CO}} p_{\mathrm{H}_{2} \mathrm{O}}-\frac{p_{\mathrm{H}_{2}} p_{\mathrm{CO}_{2}}}{K_{\mathrm{III}}}\right) \times \frac{1}{\varphi^{2}}, \\
\varphi=1+K_{\mathrm{CO}} p_{\mathrm{CO}}+K_{\mathrm{H}_{2} p_{\mathrm{H}_{2}}}+K_{\mathrm{CH}_{4}} p_{\mathrm{CH}_{4}}+K_{\mathrm{H}_{2} \mathrm{O}} \frac{p_{\mathrm{H}_{2} \mathrm{O}}}{p_{\mathrm{H}_{2}}} .
\end{gathered}
$$

The Trimm and Lam kinetic model is applied for methane combustion (Eq. (7)) as an accurate study [6, 10, 15, 43]. Due to this model has been considered for supported Pt-based catalyst, the parameters of this model are modified over Ni-based catalysts as follows [6, 10, 13, 43, 44]:

$$
\begin{aligned}
R_{4}= & \frac{K_{4 a} p_{\mathrm{CH}_{4}} p_{\mathrm{O}_{2}}}{\left(1+K_{\mathrm{CH}_{4}}^{\mathrm{C}} p_{\mathrm{CH}_{4}}+K_{\mathrm{O}_{2}}^{\mathrm{C}} p_{\mathrm{O}_{2}}\right)} \\
& +\frac{K_{4 b} p_{\mathrm{CH}_{4}} p_{\mathrm{O}_{2}}}{\left(1+K_{\mathrm{CH}_{4}}^{\mathrm{C}} p_{\mathrm{CH}_{4}}+K_{\mathrm{O}_{2}}^{\mathrm{C}} p_{\mathrm{O}_{2}}\right)} .
\end{aligned}
$$

The constants of reaction equilibrium and Arrhenius kinetic parameters are given in Table 6, and Van't Hoff parameters for species adsorption have been shown in Table $7,[6,10]$.

The formation and/or consumption rate for species $i, r_{i}\left(\mathrm{~mol} \mathrm{~kg}^{-1} \mathrm{~s}^{-1}\right)$ is ascertained by means of the reaction rates summation for that species in all of the reactions $R_{j}\left(\mathrm{~mol} \mathrm{~kg} \mathrm{~kg}^{-1} \mathrm{~s}^{-1}\right)$. In order to consider intraparticle transport limitation, $\eta_{i}$ as the effectiveness factor is applied $[6,10,15,17,44,45]$. Accordingly, the reaction rate for each species is defined by the following equations:

$$
\begin{gathered}
r_{\mathrm{CH}_{4}}=-\eta_{1} R_{1}-\eta_{2} R_{2}-\eta_{4} R_{4}, \\
r_{\mathrm{O}_{2}}=-2 \eta_{4} R_{4}, \\
r_{\mathrm{CO}_{2}}=\eta_{2} R_{2}+\eta_{3} R_{3}+\eta_{4} R_{4}, \\
r_{\mathrm{H}_{2} \mathrm{O}}=-\eta_{1} R_{1}-2 \eta_{2} R_{2}-\eta_{3} R_{3}+2 \eta_{4} R_{4}, \\
r_{\mathrm{H}_{2}}=3 \eta_{1} R_{1}+4 \eta_{2} R_{2}+\eta_{3} R_{3},
\end{gathered}
$$


Table 6. Equilibrium constants and kinetic parameters of Arrhenius for TRM reactions.

\begin{tabular}{|c|c|c|c|}
\hline Reaction, $j$ & Equilibrium constant, $K_{j}$ & $k_{\mathrm{oj}}(\mathrm{mol} /(\operatorname{kgcat} \mathrm{s}))$ & $E_{j}(\mathrm{~J} / \mathrm{mol})$ \\
\hline 1 & $K_{\mathrm{I}}=\exp \left(\frac{-26,830}{T_{s}}+30.114\right)\left(\mathrm{bar}^{2}\right)$ & $1.17 \times 10^{15}$ bar $^{0.5}$ & 240,100 \\
\hline 2 & $K_{\mathrm{II}}=K_{\mathrm{I}} \cdot K_{\mathrm{III}}\left(\mathrm{bar}^{2}\right)$ & $2.83 \times 10^{14}$ bar $^{0.5}$ & 243,900 \\
\hline 3 & $K_{\mathrm{III}}=\exp \left(\frac{4400}{T_{s}}-4.036\right)$ & $5.43 \times 10^{5} \mathrm{bar}^{-1}$ & 67,130 \\
\hline 4 & & $\begin{array}{l}8.11 \times 10^{5} \mathrm{bar}^{-2} \\
6.82 \times 10^{5} \mathrm{bar}^{-2}\end{array}$ & $\begin{array}{l}86,000 \\
86,000\end{array}$ \\
\hline \multicolumn{4}{|l|}{$1 \mathrm{bar}=100 \mathrm{kPa}$} \\
\hline$k_{j}=k_{\mathrm{oj}} \times\left(\frac{-E}{\mathbf{R T}}\right)$ & & & \\
\hline
\end{tabular}

Table 7. The parameters of Van't Hoff for species adsorption.

\begin{tabular}{|c|c|c|c|c|}
\hline Components & $K_{\text {oi }}(1 /$ bar $)$ & $\Delta \mathrm{H}_{i}(\mathrm{j} / \mathrm{mol})$ & $K_{\mathrm{oi}}^{\mathrm{C}}(1 / \mathrm{bar})$ & $\Delta \mathrm{H}_{i}^{\mathrm{C}}(\mathrm{j} / \mathrm{mol})$ \\
\hline $\mathrm{CH}_{4}$ & $6.65 \times 10^{-4}$ & $-38,280$ & & \\
\hline $\mathrm{CO}$ & $8.23 \times 10^{-5}$ & $-70,650$ & & \\
\hline $\mathrm{H}_{2}$ & $6.12 \times 10^{-9}$ & $-82,900$ & & \\
\hline $\mathrm{H}_{2} \mathrm{O}$ & $1.77 \times 10^{5}$ & 88,680 & & \\
\hline $\mathrm{CH}_{4}$ (combustion) & & & $1.26 \times 10^{-1}$ & $-27,300$ \\
\hline $\mathrm{O}_{2}$ (combustion) & & & $7.78 \times 10^{-7}$ & $-92,800$ \\
\hline \multicolumn{5}{|l|}{$\boldsymbol{K}_{i}=\boldsymbol{K}_{\mathbf{o i}} \times \exp \left(\frac{-\Delta \mathbf{H}}{\mathbf{R T}}\right)$} \\
\hline $\boldsymbol{K}_{\boldsymbol{i}}^{\mathbf{C}}=\boldsymbol{K}_{\mathbf{o i}}^{\mathbf{C}} \times \exp \left(\frac{-\Delta \mathbf{H}_{i}^{\mathrm{C}}}{\mathbf{R T}}\right)$ & & & & \\
\hline
\end{tabular}

$$
r_{\mathrm{CO}}=\eta_{1} R_{1}-\eta_{3} R_{3}
$$

where $\eta_{1}=0.07, \eta_{2}=0.06, \eta_{3}=0.7, \eta_{4}=0.05[35,45]$.

It is worth mentioning that, whereas all of the operating conditions are applied to inhibit coke formation, kinetic rates for coking and decoking reactions have been neglected.

\section{Modeling}

A one-dimensional heterogeneous reaction model that is employed as a traditional model for a catalytic reactor has been advanced to ascertain the concentration and distributions of temperature in either sides of the reactor $[6,10,15]$. This proposed model considers the mass transfer and heat transfer resistances across each side of the reactor $[6,10]$. These assumptions are applied to design this thermally-coupled reactor as below $[6,10,17]$ :

- The steady-state conditions for the reactor are considered for modeling.

- Ideality is assumed for the gas phase.

- Mass and heat axial diffusions are neglected.

- One dimensional plug flow is supposed in both sides of the reactor.
- The porosity of the bed is constant in both axial and radial directions.

- Surrounding heat loss is neglected.

To acquire the reliable equations of the mass balance and the energy balance, the differential element across the axial direction of the reactor has been presumed $[6,10]$. The applied balance equations consider convection, transfer to the solid phase, and reactions $[6,17]$.

\subsection{Balance equations for solid phase}

The solid phase equations of the mass and energy balances have been derived for either side of the reactor as below equations [10]:

$$
\begin{gathered}
a_{\mathrm{v}} c_{j} k_{\mathrm{gi}}\left(y_{i}^{\mathrm{g}}-y_{i}^{\mathrm{s}}\right)+\eta r_{i} \rho_{\mathrm{b}}=0, \\
a_{\mathrm{v}} h_{\mathrm{f}}\left(T^{\mathrm{g}}-T^{\mathrm{s}}\right)+\rho_{\mathrm{b}} \sum_{i=1}^{N} \eta r_{i}\left(\Delta H_{\mathrm{rxn}, i}\right)=0,
\end{gathered}
$$

where $T_{\mathrm{S}}$ is temperature, $y_{\text {is }}$ is the mole fraction of $i$ component in solid phase inside the reactor, and $\eta$ represents effectiveness factor (the rational relationship 
Table 8. Auxiliary correlations.

\begin{tabular}{|c|c|c|}
\hline Parameter & Equation & Ref. \\
\hline Heat capacity of component & $C_{p}=a+b T+c T^{2}+d T^{3}$ & {$[6,10,47]$} \\
\hline Heat capacity of mixture & According to local compositions & \\
\hline Reaction mixture viscosity & According to local compositions & \\
\hline Thermal conductivity of mixture & According to local compositions & {$[6,10,48]$} \\
\hline \multirow[t]{5}{*}{ Mass transfer coefficient between gas and solid phases } & $k_{\mathrm{gi}}=1.17 \mathrm{Re}^{-0.45} \mathrm{Sc}_{i}^{-0.67} u_{\mathrm{g}} \times 10^{3}$ & {$[6,10,49]$} \\
\hline & $\operatorname{Re}=\frac{2 R_{p} u_{g} \rho}{\mu}$ & \\
\hline & $\mathrm{Sc}_{i}=\frac{\mu}{\rho D_{\mathrm{im}} \times 10^{-4}}$ & \\
\hline & $D_{\mathrm{im}}=\frac{1-y_{i}}{\sum_{i \neq j}^{y_{i}}}$ & \\
\hline & $D_{i j}=\frac{10^{-7} T^{32} \sqrt{1 M_{i}+1 M_{j}}}{P\left(v_{\mathrm{ci}}{ }^{32}+v_{\mathrm{ci}}{ }^{32}\right)^{2}}$ & {$[6,10,50]$} \\
\hline Overall heat transfer coefficient & $\frac{1}{U}=\frac{1}{h_{i}}+\frac{A_{i} \ln \left(D_{o} D_{i}\right)}{2 \pi L K_{\mathrm{w}}}+\frac{A_{i}}{A_{o}} \frac{1}{h_{o}}$ & {$[6,10,48]$} \\
\hline Heat transfer coefficient between the reactor w & $\frac{h}{C_{p} \rho \mu}\left(\frac{C_{p} \mu}{k}\right)^{23}=\frac{0.485}{\varepsilon_{\mathrm{B}}}\left(\frac{\rho u d_{p}}{\mu}\right)^{-0.407}$ & {$[6,10,51]$} \\
\hline
\end{tabular}

between the observed reaction rate and the real rate of reaction) that has been acquired from the dusty gas model calculations $[6,9,10,17,46]$. The ratio of the surface areas to the catalyst pellets volume is represented by $a_{\mathrm{v}}\left(\mathrm{m}^{2} \mathrm{~m}^{-3}\right)$.

\subsection{Balance equation for fluid phase}

The mass balance and energy balance equations for either side of the reactor are expressed as below $[6,10]$ :

$$
\begin{gathered}
-\frac{1}{A_{\mathrm{C}}} \frac{\mathrm{d} F_{t, j}}{\mathrm{~d} z}+a_{\mathrm{v}} c_{j} k_{\mathrm{g} i, j}\left(y_{i, j}^{\mathrm{s}}-y_{i, j}^{\mathrm{g}}\right)=0, \\
\frac{-F_{t}}{A_{\mathrm{C}}} C_{p, j}^{\mathrm{g}} \frac{\mathrm{d} T}{\mathrm{~d} z}+a_{\mathrm{v}} h_{\mathrm{f}}\left(T_{j}^{\mathrm{s}}-T_{j}^{\mathrm{g}}\right)=0,
\end{gathered}
$$

where, $T$ is temperature, $y_{i}$ is the mole fraction of $i$ component in the fluid phase inside the reactor, and $k_{\text {gi }}$ represents the mass transfer coefficient between gas and solid phase [10]. The energy equation (Eq. (36)) includes the amount of heat which is transferred through convection and also the amount of heat which is transferred between the fluid phase and solid particle [10].

\subsection{Pressure drop}

The gaseous reaction, concentration of reactants significantly change by changing the pressure of the reactor. Consequently, it could be said that the reactions rate and yields are functions of the pressure of the reactor. Therefore, calculating the exact amount of pressure in the reactor is necessary to examine the operating of the reactor accurately. The equation of Ergun momentum balance is applied to account the pressure drop alterations across the axial direction of the reactor $[6,10,17]$ :

$$
\frac{\mathrm{d} p}{\mathrm{~d} z}=150 \frac{(1-\varepsilon)^{2} \mu u_{\mathrm{g}}}{\varepsilon^{3} d_{p}^{2}}+1.75 \frac{(1-\varepsilon) u_{\mathrm{g}}^{2} \rho}{\varepsilon^{2} d_{p}},
$$

where the pressure drop is in $\mathrm{Pa}$.

\subsection{Boundary conditions}

For the determination of boundary conditions, it was supposed that temperature, pressure, and mole fraction of gas at the entrance of the reactor are specified. Thus, the boundary conditions are considered as below at the entrance of the reactor:

$$
z=0 ; \quad y_{i}=y_{i 0}, \quad T=T_{0}, \quad P=P_{0} .
$$

\subsection{Auxiliary correlations}

To achieve the complete simulation, some of the auxiliary correlations need to be applied. The correlations approximation of mass and heat transfer between gas and solid phases and overall coefficient of heat transfer between reactor walls and gas phase in the inner side of tubes should be noticed $[6,10,17]$. Table 8 represents employed correlations for physical properties of fluids, pressure drop, dimensionless numbers, mass and heat transfer coefficient $[4,8]$. The heat transfer coefficient between the gas phase in tubes and reactor walls is usable for the heat transfer coefficient between gas and solid phases $\left(h_{\mathrm{f}}\right)$ $[6,10]$. 
Table 9. Comparison between plant data and simulated model.

\begin{tabular}{lcc}
\hline Parameter & Plant data & CSR \\
\hline Outlet temperature $\left({ }^{\circ} \mathrm{C}\right)$ & 710 & 712 \\
$\mathrm{CH}_{4}$ conversion $(\%)$ & 26.5 & 26 \\
Outlet composition $(\mathrm{mol} / \mathrm{mol})$ & & \\
Carbon dioxide & 5.71 & 5.72 \\
Carbon monoxide & 3.15 & 3.19 \\
Hydrogen & 31.39 & 31.53 \\
Methane & 20.41 & 20.33 \\
Nitrogen & 1.29 & 1.3 \\
Water (steam) & 38.05 & 37.94 \\
\hline
\end{tabular}

\subsection{Numerical solution}

In order to solve the developed model that includes a set of differential equations, the backward finite difference approximation has been used. In order to reach this purpose, the Ordinary Differential Equations (ODE), which handle any point of the reactor simultaneously, transform to a set of non-linear algebraic equations. Then the reactor length is divided into 410 discrete sections. The non-linear algebraic equations for each section of the reactor are solved using the Gauss-Newton method.

In order to validate the model, the obtained results from simulation have been compared with plant data CSR under the operating parameters. By considering Figure 1 that presents the scheme of CSR, the pre-reformed gas after being preheated is directed to the steam reformer to be more converted into $\mathrm{CO}, \mathrm{CO}_{2}$, and $\mathrm{H}_{2}$ [15]. In the CSR, the generated heat by methane combustion in a huge firedrectangular-furnace (with carbon dioxide generation and high energy consumption) is transferred to supply the required heat for the endothermic reaction [15, 17].

The results have been listed in Table 9, which verifies that simulation results are close to plant data in Zagros Petrochemical Company, Assaluyeh, Iran [6, 10].

\section{Results and discussion}

\subsection{Simulation of DRM with fired-furnace}

In this section, the performance of the DRM process by both catalysts $\mathrm{Ni}-\mathrm{K} / \mathrm{CeO}_{2}-\mathrm{Al}_{2} \mathrm{O}_{3}$ and $\mathrm{Ni} / \mathrm{La}_{2} \mathrm{O}_{3}$ is discussed by utilizing fired-furnace and compared with CSR process. In order to analyze the performance of the TCTDR, the following operating variables were applied $[6,17]$.

$$
\begin{gathered}
\mathrm{CH}_{4} \text { conversion }=\frac{F_{\mathrm{CH}_{4}, \mathrm{in}-} F_{\mathrm{CH}_{4, \text { out }}}}{F_{\mathrm{CH}_{4, \mathrm{in}}}}, \\
\mathrm{H}_{2} \text { yield }=\frac{F_{\mathrm{H}_{2, \text { out }-}} F_{\mathrm{H}_{2,} \text { in }}}{F_{\mathrm{H}_{2, \mathrm{in}}}} .
\end{gathered}
$$

(a)

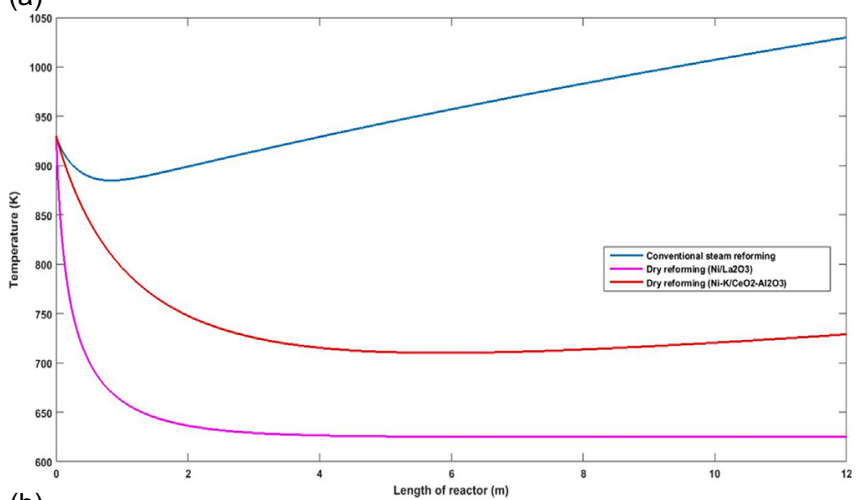

(b)

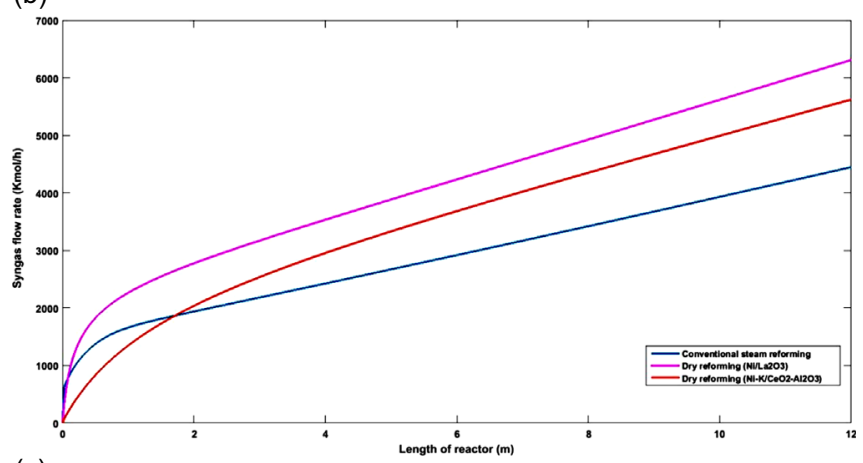

(c)

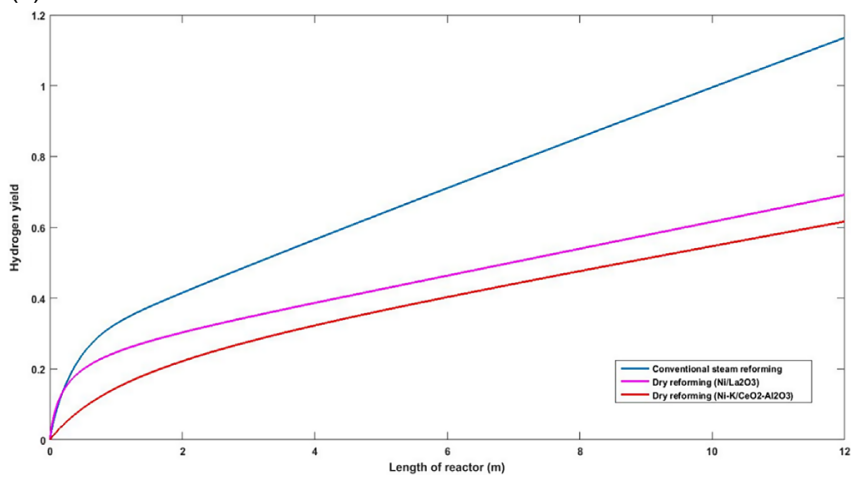

Fig. 3. (a) Comparison between the temperature profiles of CSR and DRM with fired-furnace using $\mathrm{Ni}-\mathrm{K} / \mathrm{CeO}_{2}-\mathrm{Al}_{2} \mathrm{O}_{3}$ and $\mathrm{Ni} / \mathrm{La}_{2} \mathrm{O}_{3}$ catalysts. (b) Comparison between the syngas flow rate profiles of CSR and DRM with fired-furnace using $\mathrm{Ni}-\mathrm{K}$ / $\mathrm{CeO}_{2}-\mathrm{Al}_{2} \mathrm{O}_{3}$ and $\mathrm{Ni} / \mathrm{La}_{2} \mathrm{O}_{3}$ catalyst. (c) Comparison between the Hydrogen yield profiles of CSR and DRM with fired-furnace using $\mathrm{Ni}-\mathrm{K} / \mathrm{CeO}_{2}-\mathrm{Al}_{2} \mathrm{O}_{3}$ and $\mathrm{Ni} / \mathrm{La}_{2} \mathrm{O}_{3}$ catalyst.

Figure 3, presents a direct comparison between the simulated DRM attained values of $\mathrm{CH}_{4}$ conversion, $\mathrm{H}_{2}$ yield, and syngas molar flow rate, and the simulated values of CSR. Also besides, the thermal behavior of DRM has been compared with CSR. Figure 3a depicts axial temperature profiles along CSR and DRM processes with fired-furnace. At the entrance of the reactors, the generated heat, which is utilized by the furnace, is less than the consuming heat by the endothermic reaction: consequently, so temperature decreases rapidly. In continuance, along the flow direction, 
by converting raw materials (reactant) to products, the heat dependency of process decreases, and generated heat by furnace increases the temperature of reactor, gradually in CSR. Moreover, this figure indicates that the temperature profile of SRM is higher than DRM due to the DRM process is more endothermic than CSR. These results indicated that the heat duty of fired-furnace is not sufficient for DRM, and it should be increased in design that this subject will be presented in Section 5.3.

Figure $3 \mathrm{~b}$ illustrates the syngas molar flow rate along DRM for using both catalysts and CSR reactors at the same flow rate and heat generation in fired-furnace. In the front part of either reactors as reaction taking place, the production of syngas increases rapidly. The molar flow rate of syngas reaches $4447.28 \mathrm{kmol} / \mathrm{h}$ at the outlet of CSR while at the outlet of DRM reaches $6309.36 \mathrm{kmol} / \mathrm{h}$ and $5621.2 \mathrm{kmol} / \mathrm{h}$ by $\mathrm{Ni} / \mathrm{La}_{2} \mathrm{O}_{3}$ and $\mathrm{Ni}-\mathrm{K} / \mathrm{CeO}_{2}-\mathrm{Al}_{2} \mathrm{O}_{3}$ respectively.

About consumption of $\mathrm{CH}_{4}$ results represents that $\mathrm{CH}_{4}$ conversion by DRM using $\mathrm{Ni} / \mathrm{La}_{2} \mathrm{O}_{3}$ reaches to $35.2 \%$ at the output of the reactor that is more than $\mathrm{CH}_{4}$ conversion using $\mathrm{Ni}-\mathrm{K} / \mathrm{CeO}_{2}-\mathrm{Al}_{2} \mathrm{O}_{3}$ (equal to $31.44 \%$ ) in comparison to CSR (equal to 26.5\%). In addition, Figure 3c presents $\mathrm{H}_{2}$ yield along DRM and CSR reactors. The results indicate that the $\mathrm{H}_{2}$ yield of the overall process in CSR is more than either of DRM processes and also the profile of hydrogen yield for DRM using $\mathrm{Ni} / \mathrm{La}_{2} \mathrm{O}_{3}$ over loped the profile of DRM using $\mathrm{Ni}-\mathrm{K} / \mathrm{CeO}_{2}-\mathrm{Al}_{2} \mathrm{O}_{3}$ catalyst.

The profiles of all components mole fractions variations for the DRM process using $\mathrm{Ni} / \mathrm{La}_{2} \mathrm{O}_{3}$ and $\mathrm{Ni}-\mathrm{K} / \mathrm{CeO}_{2}-$ $\mathrm{Al}_{2} \mathrm{O}_{3}$ catalysts have been plotted in Figures $4 \mathrm{a}$ and $4 \mathrm{~b}$, respectively. It can be obviously seen that $\mathrm{CH}_{4}$ and $\mathrm{CO}_{2}$ are consumed (as reactants) by reforming reactions and decrease along the reactor. Thus, on the contrary, CO and $\mathrm{H}_{2}$ are produced (as products) and increase along the length of the reactor. In either of the figures, the profiles of feeds and products behavior are precisely the same; since, both components in feed and product have the same stoichiometric coefficients. Moreover, due to this fact that the RWGS (Reverse Water Gas Shift) reaction rate along the $\mathrm{Ni}$ catalyst bed is very slow.

\subsection{Dry reforming simulation with utilizing TRM instead of fired-furnace in TCTDR}

This section presents an investigation on the applicability of replacing fired-furnace with TRM process over Ni-based catalyst to saving energy and reducing $\mathrm{CO}_{2}$ emission to the atmosphere in a TCTDR. Therefore, the behavior of the proposed configuration (TCTDR) was investigated under optimal operation conditions by comparing the methane conversion, hydrogen yield, temperature profiles, heat consumption, and kinetics of reactions in both sides of thermally coupled DRM and TRM sides. Figure 5a illustrates temperature profiles in the TRM and DRM sides of the TCTDR. As it can be observed from Figure 5a, at the entrance of the TRM side, the exothermic oxidation reaction is dominant due to a huge amount of heat, which is generated via partial and complete methane combustion reactions hence along flow direction in the front part of TRM the temperature begins to increase rapidly.
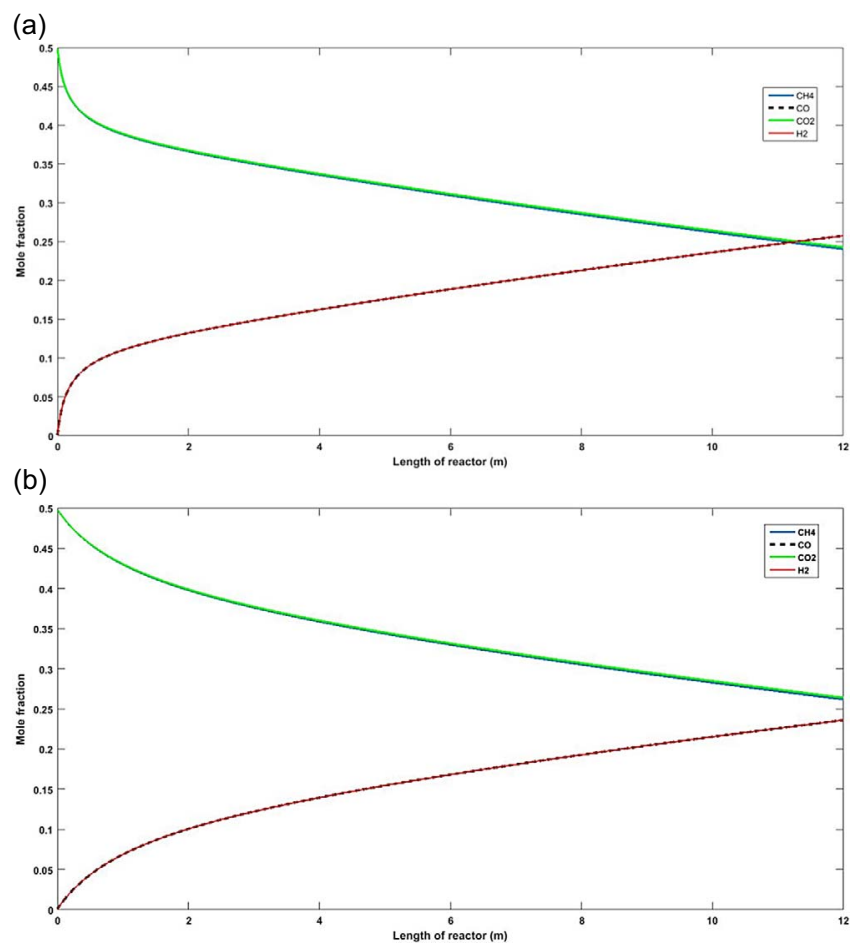

Fig. 4. Variation of all components mole fraction along DRM with fired-furnace using (a) $\mathrm{Ni} / \mathrm{La}_{2} \mathrm{O}_{3}$ and (b) $\mathrm{Ni}-\mathrm{K} / \mathrm{CeO}_{2}-$ $\mathrm{Al}_{2} \mathrm{O}_{3}$ catalysts.

The generated heat is utilized to proceed the endothermic reaction, which taking place during the rest of the TRM side and also transfer through the tube wall to the DRM side to proceed the DRM process. Consequently, the temperature decreases gradually along the rest of the TRM side. The endothermic reactions taking place along the length of the DRM side, therefore endothermic reactions dominate the whole process in the DRM side (see Fig. 5a). Whereas the amount of heat which is transferred to DRM side is lower than the consumed heat via DRM side, in the front part of DRM side the temperature begins to decrease rapidly but in continuation by the reactants consuming and decreasing in reactions rate the heat affinity of process decreases and subsequently temperature reduces along the DRM side of the reactor slightly.

Figure 5b displays the variations of methane conversion along the length of the DRM and TRM sides of the TCTDR. It can be evidently seen that the methane conversion by TRM (almost 88\%) is significantly higher than DRM side ( $16.98 \%$ using $\mathrm{Ni} / \mathrm{La}_{2} \mathrm{O}_{3}$ and employing $15.88 \%$ for $\mathrm{Ni}-\mathrm{K} / \mathrm{CeO}_{2}-\mathrm{Al}_{2} \mathrm{O}_{3}$ catalyst) due to the reaction between oxygen and methane is more favorable than the reaction between methane and carbon dioxide [35]. It can also be observed that at the first part of the TRM side, the methane conversion increases rapidly due to methane oxidation reaction taking place at this section, but after consumption of oxygen, the remaining methane is converted by steam reforming and dry reforming reactions. Therefore, the methane conversion rate decreases gradually along the reactor. 
(a)
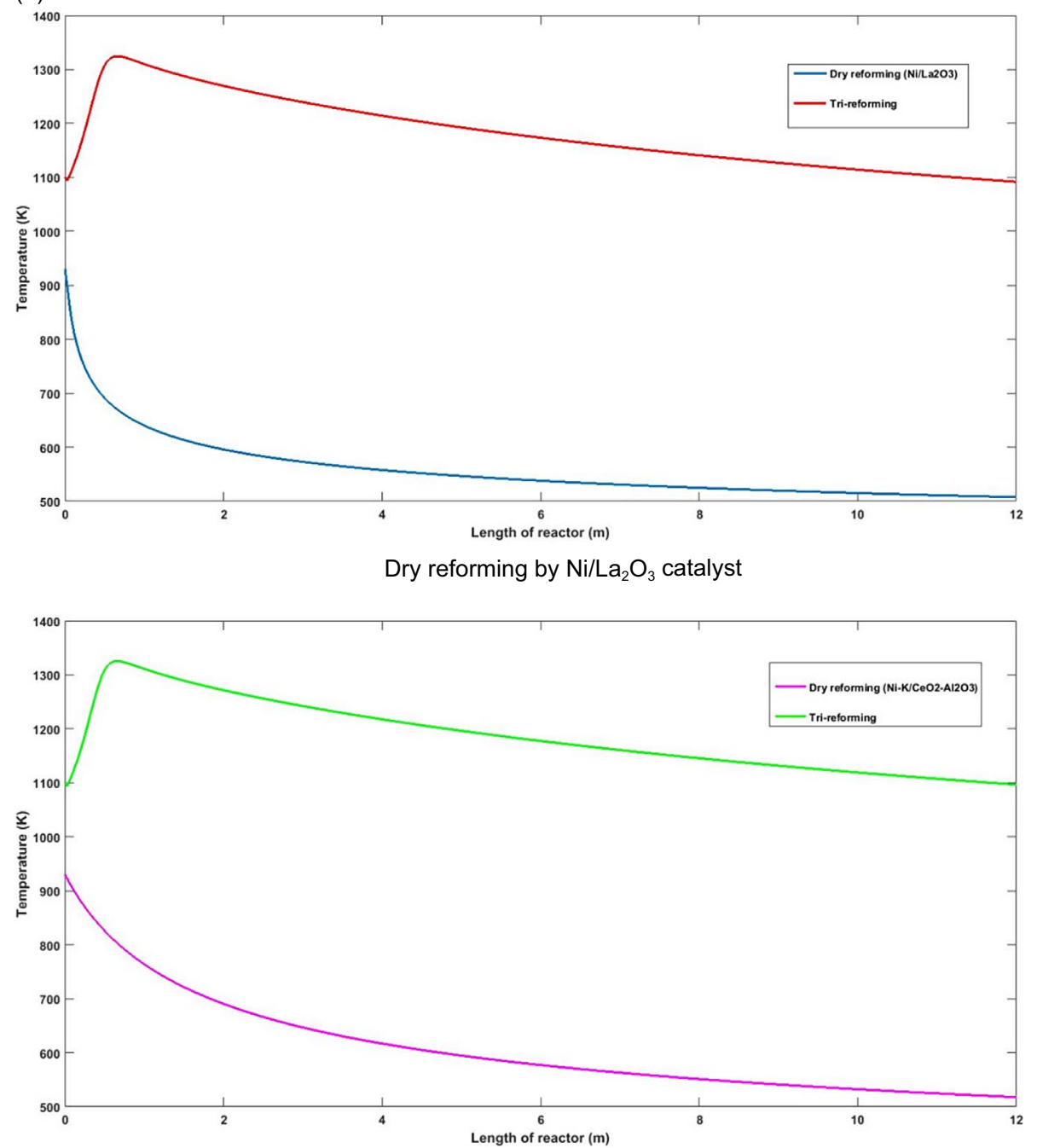

(b)

Dry reforming by $\mathrm{Ni}-\mathrm{K} / \mathrm{CeO}_{2}-\mathrm{Al}_{2} \mathrm{O}_{3}$ catalyst

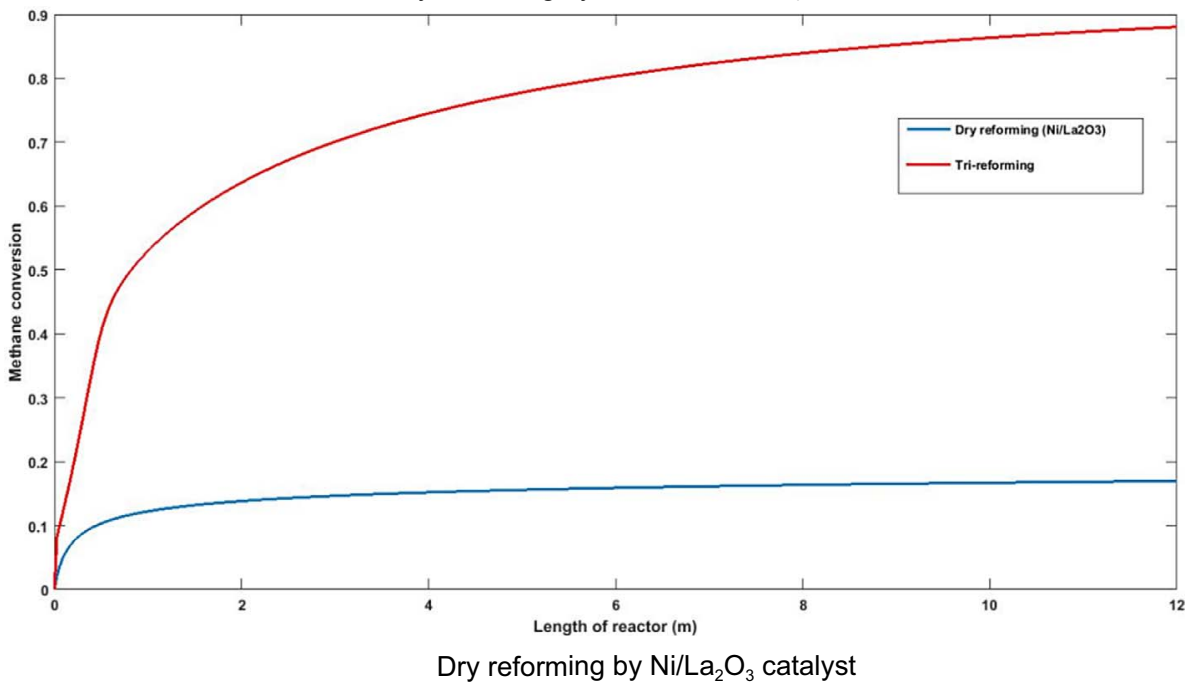

Fig. 5. (a) Comparison between the temperature profiles of the DRM side and TRM sides of TCTDR by $\mathrm{Ni}_{2} / \mathrm{La}_{2} \mathrm{O}_{3}$ catalyst in DRM and by $\mathrm{Ni}-\mathrm{K} / \mathrm{CeO}_{2}-\mathrm{Al}_{2} \mathrm{O}_{3}$ in DRM. (b) Comparison between the methane conversion profiles of the DRM side and TRM sides of TCTDR by $\mathrm{Ni} / \mathrm{La}_{2} \mathrm{O}_{3}$ catalyst in DRM and by $\mathrm{Ni}-\mathrm{K} / \mathrm{CeO}_{2}-\mathrm{Al}_{2} \mathrm{O}_{3}$ in DRM. (c) Comparison between the hydrogen yield profiles of the DRM side and TRM sides of TCTDR by Ni/La $\mathrm{O}_{3}$ catalyst in DRM and by $\mathrm{Ni}-\mathrm{K} / \mathrm{CeO}_{2}-\mathrm{Al}_{2} \mathrm{O}_{3}$ in $\mathrm{DRM}$. 


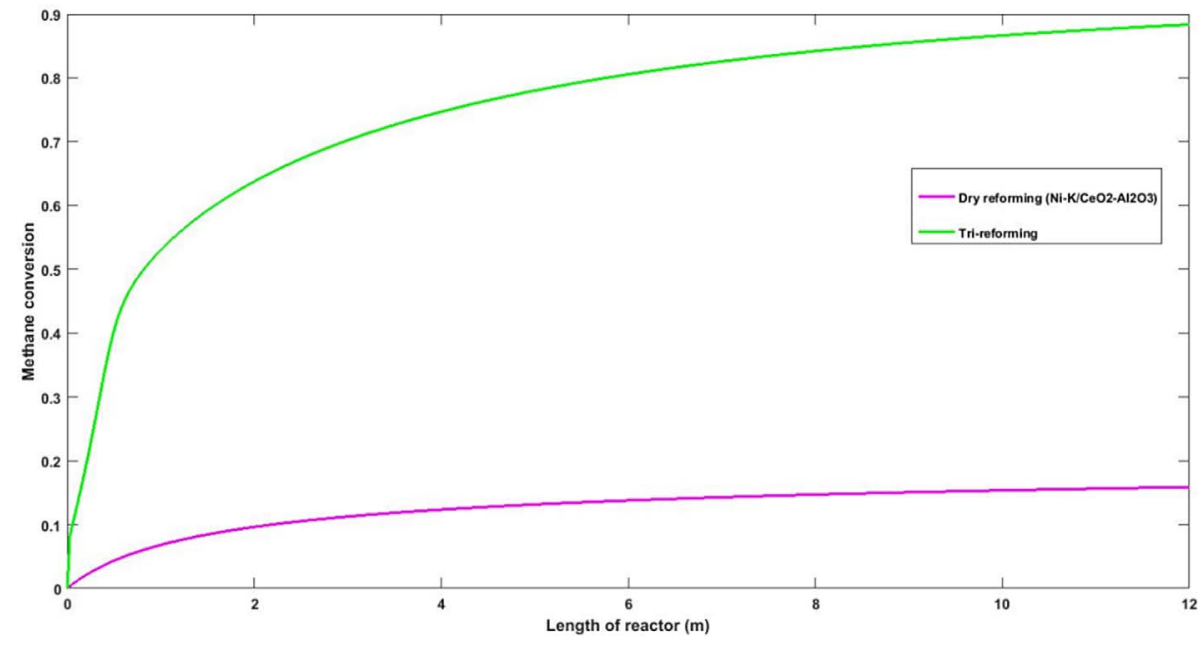

(c)

Dry reforming by $\mathrm{Ni}-\mathrm{K} / \mathrm{CeO}_{2}-\mathrm{Al}_{2} \mathrm{O}_{3}$ catalyst
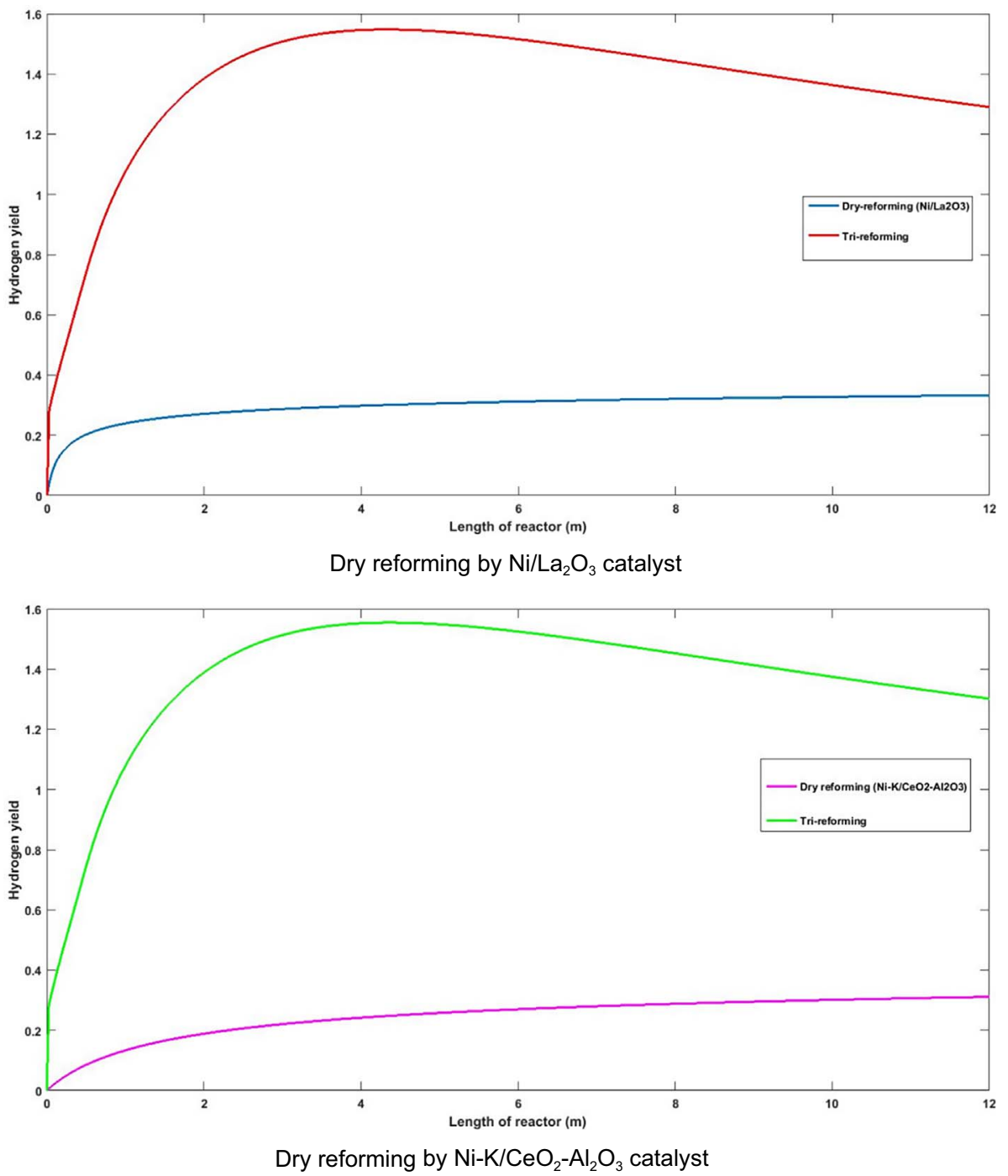

Fig. 5. Continued. 
(a)

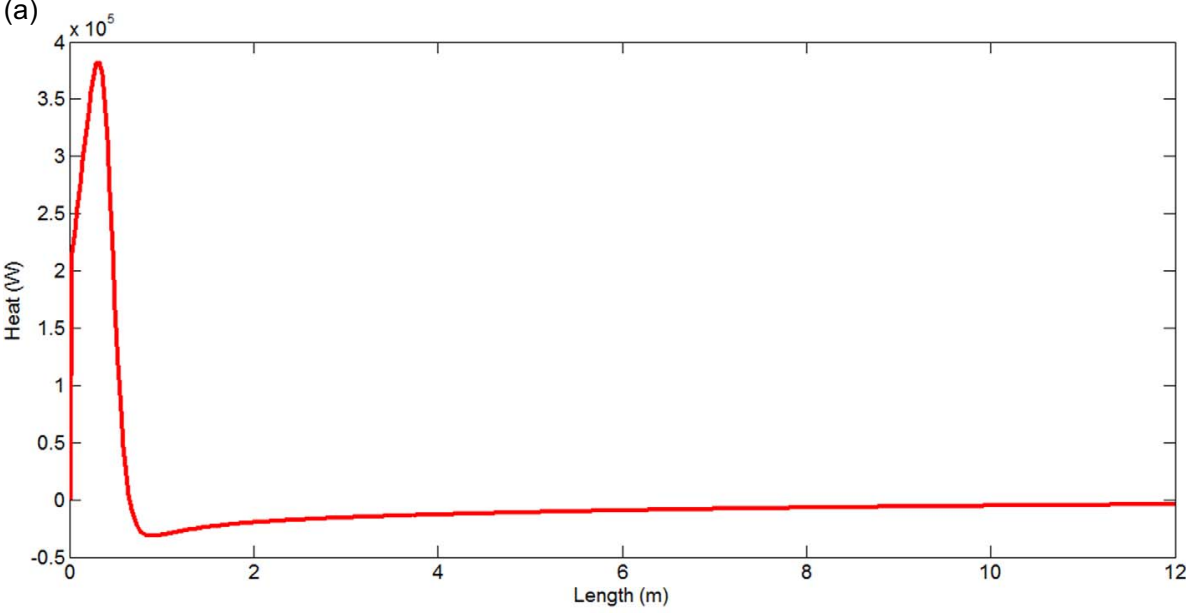

(b)

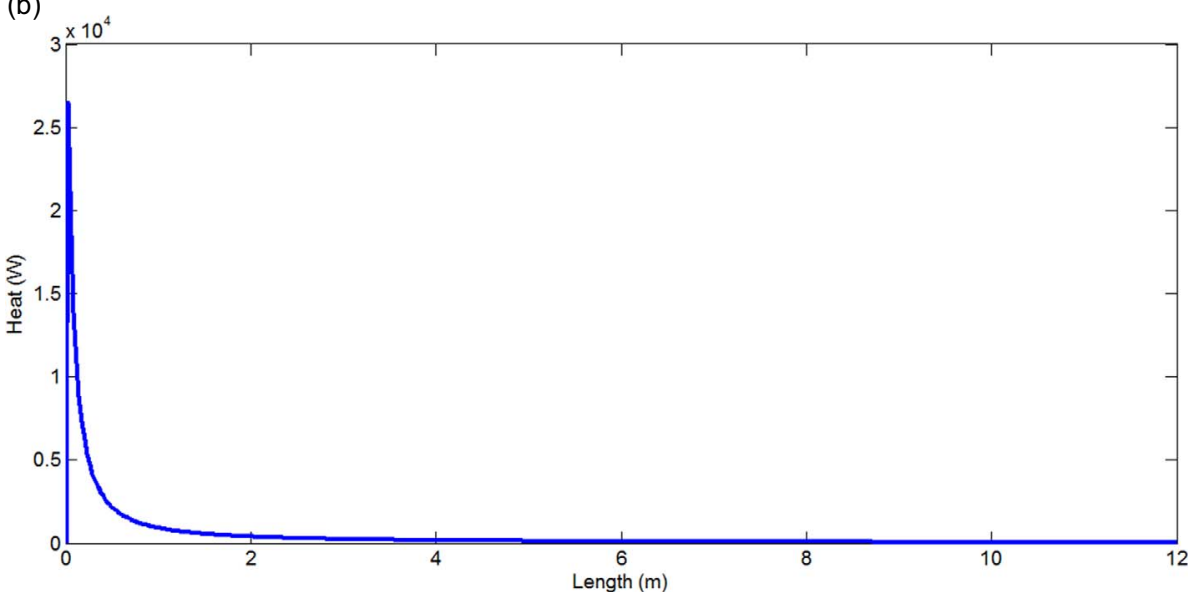

Fig. 6. Changes in the heat along (a) tri-reforming side and (b) dry reforming side of TCTDR.

The axial $\mathrm{H}_{2}$ yield profiles of thermally coupled reactors have been plotted in Figure 5c. It is evident that the $\mathrm{H}_{2}$ yield along TRM is considerably higher than the DRM side. It is found that $\mathrm{H}_{2}$ yield goes through a maximum value along the $4 \mathrm{~m}$ length of the reactor, and after that, $\mathrm{H}_{2}$ yield decreases slightly due to it be affected by water gas shift reaction.

Figure 6 demonstrates changes in heat generation and heat consumption for both sides of the thermally coupled reactor. Along flow direction, a massive quantity of heat is produced via methane oxidation reaction in the front part of TRM. The generated heat is consumed by endothermic reactions to proceed steam reforming and dry reforming reactions of the TRM side, and also, the rest part of this energy is transferred to the DRM side through the tube wall to proceed dry reforming reaction in DRM side. At the entrance of the DRM side, energy is considerably consumed to drive the dry reforming reaction. As mentioned before, the amount of heat consumption along the DRM side of TCTDR is more than the amount of heat which is transferred by the TRM side of TCTDR, in continuation, decreasing the rate of reactions in both sides of TCTDR cause to reducing in the heat transfer rate between both sides of TCTDR.
Figures $7 \mathrm{a}$ and $7 \mathrm{~b}$ show the reactions rate profiles along the DRM and the TRM side of TCTDR. The rate of dry reforming reaction at the entrance of the DRM side is high due to the high temperature and existence of an abundant amount of $\mathrm{CH}_{4}$ and $\mathrm{CO}_{2}$ [10]. After that, dry reforming rate begins to decrease due to temperature decreasing and decrease in reactants amount [10]. The obtained results indicate that near the entrance of the TRM side, the methane oxidation reaction controls the kinetic conditions of the TRM process until most of the oxygen is consumed completely and its reaction rate reaches zero [10]. Then endothermic reactions (dry reforming and steam reforming) control the conditions of the TRM process kinetically, and about after $1 \mathrm{~m}$ length of the reactor, the rate of these endothermic reactions decreases slightly [10]. After a short length of TRM side, the WGS reaction rate comes to be negative because of the high RWGS reaction rate is favorable at a high concentration of $\mathrm{CO}_{2}$ and high temperature $[6,10]$.

The comparison between CSR and TCTDR depicts that the TCTDR has benefits such as two types of syngas production and energy consumption reduction. In TCTDR the required energy is supplied by TRM reaction and low-performance fired-furnace is eliminated while in CSR, enormous amount of energy which equals to $69 \mathrm{MW}$ is 
(a)

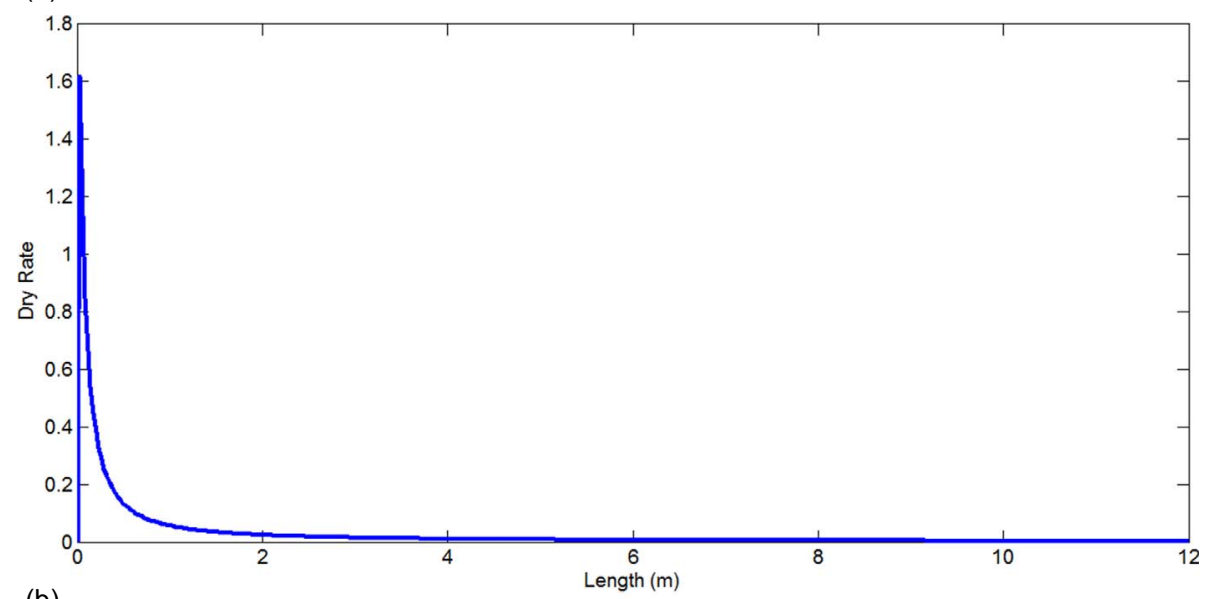

(b)

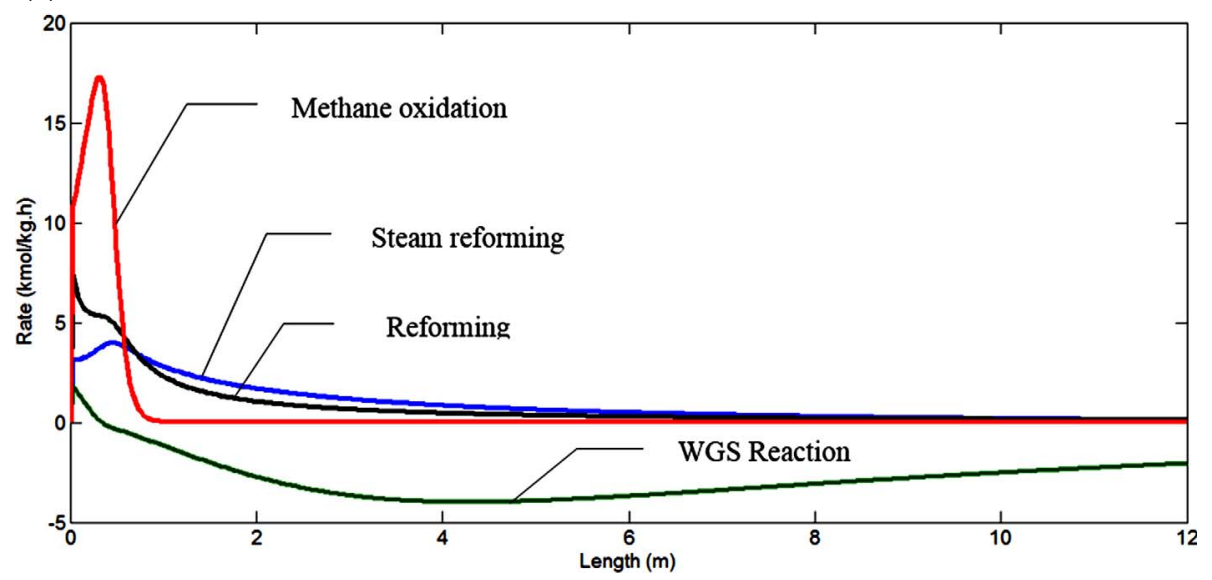

Fig. 7. (a) Variation of reaction rate along the DRM side of TCTDR. (b) Variation of reaction rates along the TRM side of TCTDR.

prepared by low-performance fired-furnace which consumes methane as feed and produces $\mathrm{CO}_{2}$ as green house gas and meanwhile has a substantial effect on global warming $[10,15]$. Another profit of TCTDR is its coke resistive ability due to the oxygen and steam presence in feed flow [42]. The existence of oxygen and steam improves the coke removal mechanism in the TRM side of the TCTDR reactor, while one of the main problems of methane reforming reactions is coke formation over the active surface, which leads to the deactivation of the catalyst [10, 35]. Also, it must be noted the adjusting of operating conditions of TCTDR such as temperature, type of the catalyst could significantly eliminate coke deposition during the process $[10,35]$.

This proposed thermally coupling of dry and trireforming of methane (TCTDR) is performed by $\mathrm{O}_{2}$, $\mathrm{H}_{2} \mathrm{O}$, and a huge amount of $\mathrm{CO}_{2}$ as a co-feed with natural gas (methane) and pre-reformed gas [35]. Therefore according to the elimination of low-performance fired-furnace and global concern about $\mathrm{CO}_{2}$ conversion and utilization, it could be affirmed that this proposed configuration is an energy-saving and environment-friendly process which produces syngas with a quality $\left(\mathrm{H}_{2} / \mathrm{CO}_{2}\right)$ of close to 1 using low cost and abundant Ni-based catalyst [35].

\subsection{Heat generation effect on DRM performance with utilizing fired-furnace}

This section analyzes the effect of heat generation on the performance of DRM with fired-furnace configuration. In order to achieve this purpose, the alterations trend of heat generation against variations of $\mathrm{CH}_{4}$ conversion, $\mathrm{H}_{2}$ yield, syngas flow rate, and temperature have been simulated. Figures $8 \mathrm{a}$ and $8 \mathrm{~b}$ illustrate the effect of heat generation on syngas flow rate along the DRM process using $\mathrm{Ni} / \mathrm{La}_{2} \mathrm{O}_{3}$ and $\mathrm{Ni}-\mathrm{K} / \mathrm{CeO}_{2}-\mathrm{Al}_{2} \mathrm{O}_{3}$ catalysts. As it can be seen, as the heat generation is enlarged for two times, the syngas flow rate reaches from $5612 \mathrm{kmol} / \mathrm{h}$ to $7787 \mathrm{kmol} / \mathrm{h}$ for $\mathrm{Ni}-\mathrm{K} /$ $\mathrm{CeO}_{2}-\mathrm{Al}_{2} \mathrm{O}_{3}$ catalyst and reaches from $6309 \mathrm{kmol} / \mathrm{h}$ to $9082 \mathrm{kmol} / \mathrm{h}$ for $\mathrm{Ni} / \mathrm{La}_{2} \mathrm{O}_{3}$ catalyst. This is due to dry reforming is the endothermic process and increasing the heat generation cause to enhance the reaction rate.

Changes of $\mathrm{H}_{2}$ yield along DRM versus heat generation is shown in Figures $9 \mathrm{a}$ and $9 \mathrm{~b}$. Higher heat generation leads to reach higher $\mathrm{H}_{2}$ yield for the DRM side. The highest output $\mathrm{H}_{2}$ yield of DRM is attained at the maximum amount of heat generation, which are 0.854 and 0.997 for $\mathrm{Ni}-\mathrm{K} / \mathrm{CeO}_{2}-\mathrm{Al}_{2} \mathrm{O}_{3}$ and $\mathrm{Ni} / \mathrm{La}_{2} \mathrm{O}_{3}$ catalysts, respectively. 


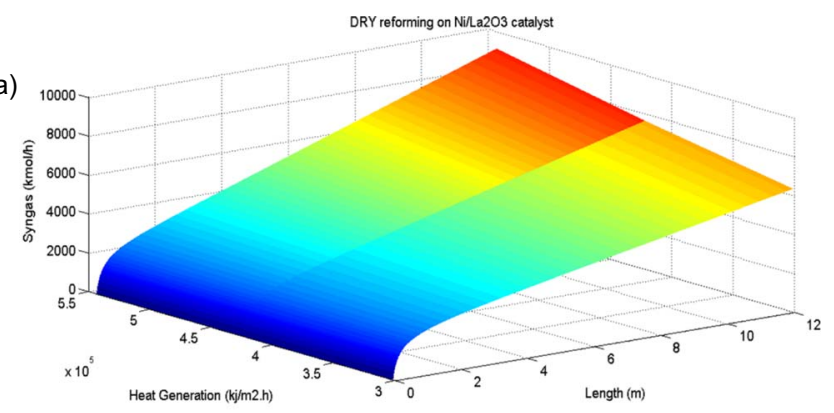

(a)

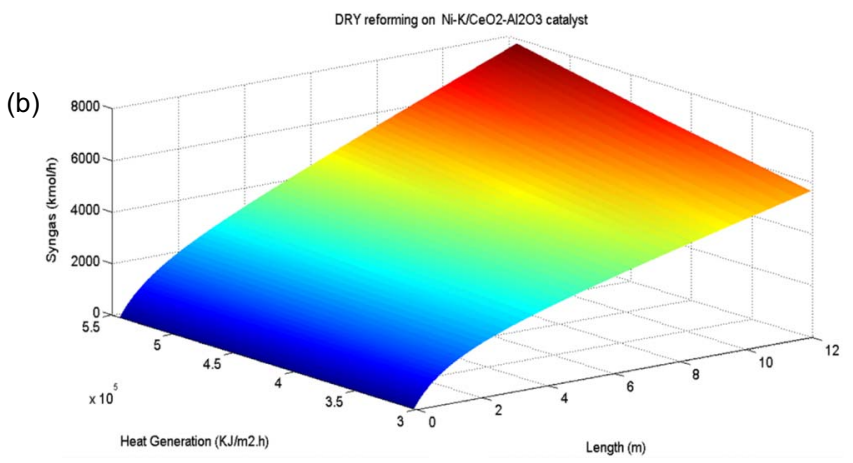

Fig. 8. (a) Effect of heat generation on syngas flow rate at length of DRM reformer with fired-furnace configuration using $\mathrm{Ni} / \mathrm{La}_{2} \mathrm{O}_{3}$. (b) Effect of heat generation on syngas flow rate at length of DRM reformer with fired-furnace configuration using $\mathrm{Ni}-\mathrm{K} / \mathrm{CeO}_{2}-\mathrm{Al}_{2} \mathrm{O}_{3}$.

(a)

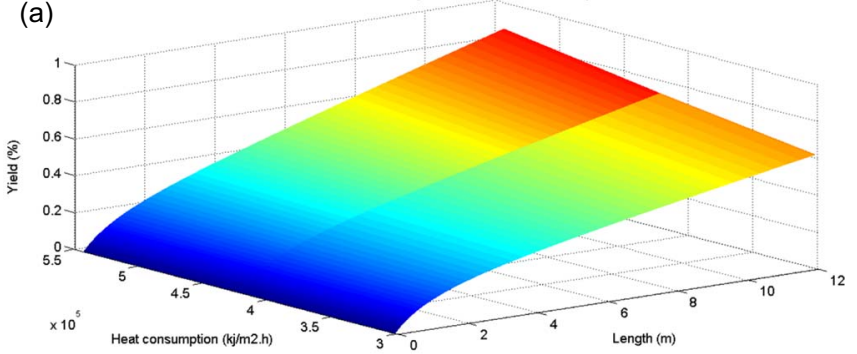

(b)

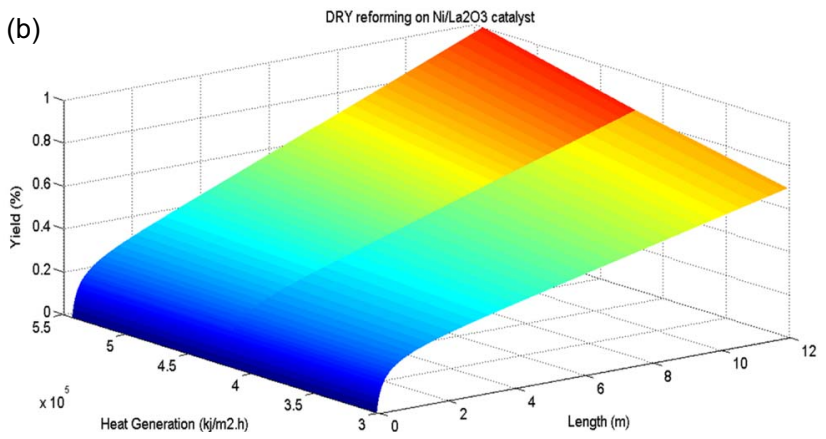

Fig. 9. (a) Effect of heat generation on hydrogen yield at length of DRM reformer with fired-furnace configuration using $\mathrm{Ni}-\mathrm{K} /$ $\mathrm{CeO}_{2}-\mathrm{Al}_{2} \mathrm{O}_{3}$. (b) Effect of heat generation on hydrogen yield at length of DRM reformer with fired-furnace configuration using $\mathrm{Ni} / \mathrm{La}_{2} \mathrm{O}_{3}$. (a)

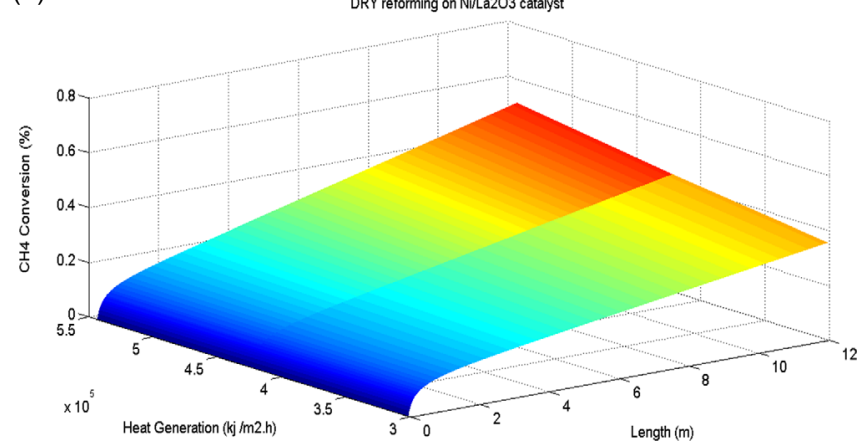

(b)

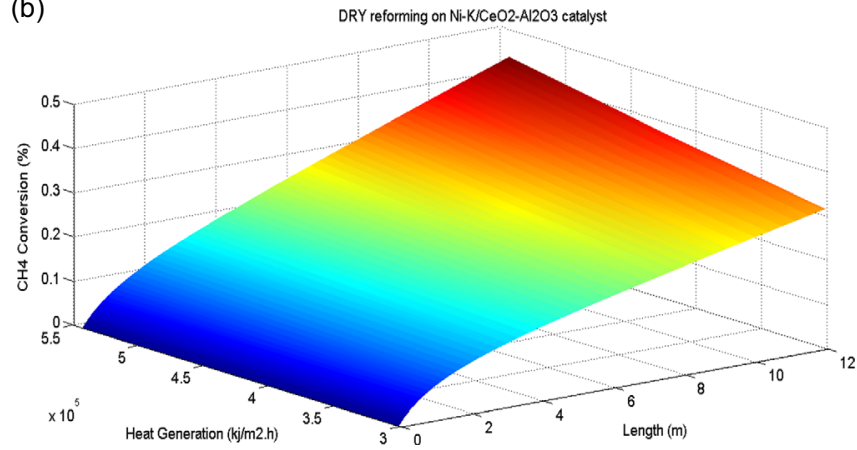

Fig. 10. (a) Effect of heat generation on methane conversion at length of DRM reformer with fired-furnace configuration using $\mathrm{Ni} / \mathrm{La}_{2} \mathrm{O}_{3}$. (b) Effect of heat generation on methane conversion at length of DRM reformer with fired-furnace configuration using $\mathrm{Ni}-\mathrm{K} / \mathrm{CeO}_{2}-\mathrm{Al}_{2} \mathrm{O}_{3}$.

(a)
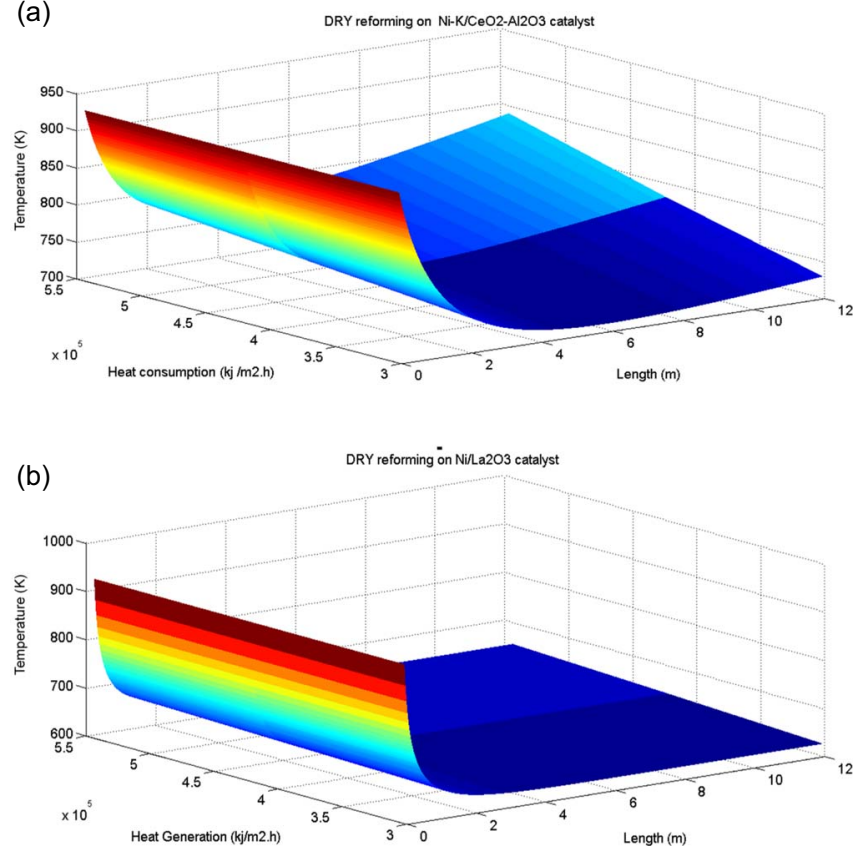

Fig. 11. (a) Effect of heat generation on temperature behavior at length of DRM reformer with fired-furnace configuration using $\mathrm{Ni}-\mathrm{K} / \mathrm{CeO}_{2}-\mathrm{Al}_{2} \mathrm{O}_{3}$. (b) Effect of heat generation on temperature behavior at length of DRM reformer with firedfurnace configuration using $\mathrm{Ni} / \mathrm{La}_{2} \mathrm{O}_{3}$. 
Figures 10a and 10b illustrated the effect of heat generation on methane conversion in the endothermic DRM reaction in DRM reformer with fired-furnace configuration. It is evident that the increase in heat generation leads to increase in methane conversion by $\mathrm{Ni} / \mathrm{La}_{2} \mathrm{O}_{3}$ catalyst more significantly than methane conversion by $\mathrm{Ni}-\mathrm{K} / \mathrm{CeO}_{2}-\mathrm{Al}_{2} \mathrm{O}_{3}$ catalyst. When the heat generation is enlarged for two times, the methane conversion gradually increases to $50.85 \%$ and $43.59 \%$ for $\mathrm{Ni} / \mathrm{La}_{2} \mathrm{O}_{3}$ and $\mathrm{Ni}-\mathrm{K} / \mathrm{CeO}_{2}-\mathrm{Al}_{2} \mathrm{O}_{3}$ catalysts, respectively.

Figures $11 \mathrm{a}$ and $11 \mathrm{~b}$ represent the effect of various heat generation on temperature behavior of DRM reaction in DRM reformer with fired-furnace configuration. By increasing the supplying heat for the DRM process using fired-furnace, the temperature profile increases from $728.8 \mathrm{~K}$ to $838 \mathrm{~K}$ and from $625 \mathrm{~K}$ to $645 \mathrm{~K}$ for $\mathrm{Ni}-\mathrm{K} /$ $\mathrm{CeO}_{2}-\mathrm{Al}_{2} \mathrm{O}_{3}$ and $\mathrm{Ni} / \mathrm{La}_{2} \mathrm{O}_{3}$ catalysts respectively. As it can be seen, the temperature decreases rapidly due to the required heat in the endothermic side of the reactor is more than the amount of transferred heat through the tube wall from the exothermic side of the thermally coupled reactor. According to the results of this section, it is inferred that the $\mathrm{Ni} / \mathrm{La}_{2} \mathrm{O}_{3}$ catalyst is more efficient than $\mathrm{K} / \mathrm{CeO}_{2}-$ $\mathrm{Al}_{2} \mathrm{O}_{3}$ catalyst for the dry reforming reaction. Of course, some practical insights should be considered for increasing more heat generation by the furnace (more combustion of fuel gas and reformer duty) in industrial scale manufacturing.

\section{Conclusion}

In the current study, two proposed configuration was simulated including utilizing of fired-furnace for DRM and employing TRM for heat supplying and effect of different amount of providing energy on performance of DRM process with fired-furnace was studied. In fact, the application of TRM as a heat source for DRM reaction to syngas production in TCTDR by abundant and affordable Ni-based catalyst has been proposed. The proposed reactors were simulated using a one-dimensional heterogeneous mathematical model numerically. In order to validate the proposed model, the simulation results, which obtained from the simulation of CSR were compared with plant data, which were very well fit together. The obtained results from simulations of DRM with fired-furnace configuration showed that molar flow rate syngas at of DRM reaches to $6309 \mathrm{kmol} / \mathrm{h}$ and $5621 \mathrm{kmol} / \mathrm{h}$ by $\mathrm{Ni} / \mathrm{La}_{2} \mathrm{O}_{3}$ and $\mathrm{Ni}-\mathrm{K} / \mathrm{CeO}_{2}-\mathrm{Al}_{2} \mathrm{O}_{3}$ respectively in comparison to syngas production equal to $4447.28 \mathrm{kmol} / \mathrm{h}$ in CSR. Also, Dry reforming simulation with utilizing TRM instead of firedfurnace in TCTDR presented that the molar flow rate of syngas out of DRM and TRM sides were $2907 \mathrm{kmol} / \mathrm{h}$ using $\mathrm{Ni}-\mathrm{K} / \mathrm{CeO}_{2}-\mathrm{Al}_{2} \mathrm{O}_{3}$ catalyst and $49,278 \mathrm{kmol} / \mathrm{h}$ using $\mathrm{NiO}-\mathrm{Mg} / \mathrm{Ce}-\mathrm{ZrO}_{2} / \mathrm{Al}_{2} \mathrm{O}_{3}$ respectively. In addition, the flow rate of syngas out of DRM and TRM sides of TCTDR were $3043 \mathrm{kmol} / \mathrm{h}$ using $\mathrm{Ni} / \mathrm{La}_{2} \mathrm{O}_{3}$ catalyst and $49,047 \mathrm{kmol} / \mathrm{h}$ using $\mathrm{NiO}-\mathrm{Mg} / \mathrm{Ce}-\mathrm{ZrO}_{2} / \mathrm{Al}_{2} \mathrm{O}_{3}$ respectively. Also, as the heat generation is enlarged for two times in DRM with fired-furnace configuration, the syngas flow rate reaches from $5612 \mathrm{kmol} / \mathrm{h}$ to $7787 \mathrm{kmol} / \mathrm{h}$ for $\mathrm{Ni}-\mathrm{K} / \mathrm{CeO}_{2}-\mathrm{Al}_{2} \mathrm{O}_{3}$ catalyst and reaches from $6309 \mathrm{kmol} / \mathrm{h}$ to $9082 \mathrm{kmol} / \mathrm{h}$ for $\mathrm{Ni} / \mathrm{La}_{2} \mathrm{O}_{3}$ catalyst.

The TCTDR configuration is an economic and profit way for syngas production due to prevent enormous emission of $\mathrm{CO}_{2}$ to the atmosphere by consuming enormous amount of $\mathrm{CO}_{2}$ in order to produce syngas with deferent quality from both sides of reactor which has been filled with economic Ni-based catalyst and also due to elimination of low performance fired-furnace by substituting it with TRM process to supply the required energy for DRM process. Finally, more effort should be conducted to the commercialization of this proposed configuration by including the investigation of capital cost, operating cost, and environmental aspects to divulge the applicability of syngas production from TCTDR on an industrial scale. Also, it must be noted that one of the key disadvantages and limitations of dry or tri-reforming would be accelerated catalyst deactivation and it needs to consider catalyst deactivation in the kinetics rate expressions using dynamic simulation in future researches. If fact, a comprehensive dynamic simulation is needed to study the performance of process with time as a particular research paper because deactivation of the catalyst on the two sides will further aggravate the heat balance and operational parameters should be changed properly with time.

\section{References}

1 Shen J., Reule A.A.C., Semagina N. (2019) Ni/ $\mathrm{MgAl}_{2} \mathrm{O}_{4}$ catalyst for low-temperature oxidative dry methane reforming with $\mathrm{CO}_{2}$, Int. J. Hydrogen Energy 44, 10, 4616-4629.

2 Abdalla A.M., Hossain S., Nisfindy O.B., Azad A.T., Dawood M., Azad A.K. (2018) Hydrogen production, storage, transportation and key challenges with applications: A review, Energy Convers. Manage. 165, 602-627.

3 Li L., Tang D., Song Y., Jiang B., Zhang Q. (2018) Hydrogen production from ethanol steam reforming on $\mathrm{Ni}-\mathrm{Ce} / \mathrm{MMT}$ catalysts, Energy 149, 937-943.

4 Passalacqua R., Centi G., Perathoner S. (2015) Solar production of fuels from water and $\mathrm{CO}_{2}$ : Perspectives and opportunities for a sustainable use of renewable energy, Oil Gas Sci. Technol. - Rev. IFP Energies nouvelles 70, 799-815.

5 Tursunov O., Kustov L., Kustov A. (2017) A brief review of carbon dioxide hydrogenation to methanol over copper and iron based catalysts, Oil Gas Sci. Technol. - Rev. IFP Energies nouvelles 72, 30-39.

6 Rahnama H., Farniaei M., Abbasi M., Rahimpour M.R. (2014) Modeling of synthesis gas and hydrogen production in a thermally coupling of steam and tri-reforming of methane with membranes, J. Ind. Eng. Chem. 20, 4, 1779-1792.

7 Sengodan S., Lan R., Humphreys J., Du D., Xu W., Wang H., Tao S. (2018) Advances in reforming and partial oxidation of hydrocarbons for hydrogen production and fuel cell applications, Renew. Sustain. Energy Rev. 82, 761-780.

8 Aziz M.A.A., Setiabudi H.D., Teh L.P., Annuar N.H.R., Jalil A.A. (2018) A review of heterogeneous catalysts for syngas production via dry reforming, J. Taiwan Inst. Chem. Eng. 101, 139-158. 
9 Abdulrasheed A., Jalil A.A., Gambo Y., Ibrahim M., Hambali H.U., Yusuf M., Hamid S. (2019) A review on catalyst development for dry reforming of methane to syngas: Recent advances, Renew. Sustain. Energy Rev. 108, 175-193.

10 Farniaei M., Abbasi M., Rahnama H., Rahimpour M.R., Shariati A. (2014) Syngas production in a novel methane dry reformer by utilizing of tri-reforming process for energy supplying: Modeling and simulation, J. Nat. Gas Sci. Eng. 20, 132-146.

11 Papari S., Kazemeini M., Fattahi M. (2013) Modelling-based optimisation of the direct synthesis of dimethyl ether from syngas in a commercial slurry reactor, Chin. J. Chem. Eng. 21, 6, 611-621.

12 Chu R., Hou W., Meng X., Xu T., Miao Z., Wu G., Bai L. (2016) Catalytic kinetics of dimethyl ether one-step synthesis over $\mathrm{CeO}_{2}-\mathrm{CaO}-\mathrm{Pd} / \mathrm{HZSM}-5$ catalyst in sulfur-containing syngas process, Chin. J. Chem. Eng. 24, 12, 1735-1741.

13 Gangadharan P., Kanchi K.C., Lou H.H. (2012) Evaluation of the economic and environmental impact of combining dry reforming with steam reforming of methane, Chem. Eng. Res. Des. 90, 11, 1956-1968.

14 Jianjun H., Li D., Lee D.J., Zhang Q., Wang W., Zhao S., Zhang Z., He C. (2019) Integrated gasification and catalytic reforming syngas production from corn straw with mitigated greenhouse gas emission potential, Bioresour. Technol. 280, 371-377.

15 Arab Aboosadi Z., Jahanmiri A.H., Rahimpour M.R. (2011) Optimization of tri-reformer reactor to produce synthesis gas for methanol production using differential evolution (DE) method, Appl. Energy 88, 8, 2691-2701.

16 Kumar R., Kumar K., Choudary N.V., Pant K.K. (2019) Effect of support materials on the performance of Ni-based catalysts in tri-reforming of methane, Fuel Process. Technol. 186, $40-52$.

17 Farniaei M., Rahnama H., Abbasi M., Rahimpour M.R. (2013) Simultaneous production of two types of synthesis gas by steam and tri-reforming of methane using an integrated thermally coupled reactor: Mathematical modeling, Int. J. Energy Res. 38, 1260-1277.

18 Zhang Y., Cruz J., Zhang S., Lou H.H., Benson T.J. (2013) Process simulation and optimization of methanol production coupled to tri-reforming process, Int. J. Hydrogen Energy 38, 31, 13617-13630.

19 Cloete S., Khan M.N., Amini S. (2019) Economic assessment of membrane-assisted autothermal reforming for cost effective hydrogen production with $\mathrm{CO}_{2}$ capture, Int. J. Hydrogen Energy 44, 7, 3492-3510.

20 Jahangiri A., Saidi M., Mohammadi A., Sedighi M. (2017) Characterization and catalytic reactivity of LaNi1- $\mathrm{xMgxO}_{3}-\delta$ perovskite oxides in reforming of methane with $\mathrm{CO}_{2}$ and $\mathrm{O}_{2}$, Int. J. Chem. React. Eng. 16, 4.

21 Özkara-Aydınoğlu Ş., Özensoy E., Aksoylu A.E. (2009) The effect of impregnation strategy on methane dry reforming activity of Ce promoted $\mathrm{Pt} / \mathrm{ZrO}_{2}$, Int. J. Hydrogen Energy 34, 24, 9711-9722.

22 Wang Y., Yao L., Wang Y., Wang S., Zhao Q., Mao D., Hu C. (2018) Low-temperature catalytic $\mathrm{CO}_{2}$ dry reforming of methane on $\mathrm{Ni}-\mathrm{Si} / \mathrm{ZrO}_{2}$ catalyst, ACS Catal. 8, 7, 6495-6506.

23 Ma Q., Guo L., Fang Y., Li H., Zhang J., Zhao T.S., Yang G., Yoneyama Y., Tsubaki N. (2019) Combined methane dry reforming and methane partial oxidization for syngas production over high dispersion Ni based mesoporous catalyst, Fuel Process. Technol. 188, 98-104.
24 Rameshan C., Li H., Anic K., Roiaz M., Pramhaas V., Rameshan R., Blume R., Hävecker M., Knudsen J., KnopGericke A. (2018) In situ NAP-XPS spectroscopy during methane dry reforming on $\mathrm{ZrO}_{2} / \operatorname{Pt}\left(\begin{array}{lll}1 & 1 & 1\end{array}\right)$ inverse model catalyst, J. Phys.: Condens. Matter. 30, 264007.

25 Song C. (2001) Tri-reforming: a new process for reducing $\mathrm{CO}_{2}$ emissions, Chem. Innov. 31, 1, 6-21.

26 Chein R.Y., Hsu W.H. (2018) Thermodynamic analysis of syngas production via tri-reforming of methane and carbon gasification using flue gas from coal-fired power plants, J. Cleaner Prod. 20, 242-258.

27 Hassan A.M., Jim P., Valerie S., Jin L.W., Selvakannan P., Deepa D., Tibra M., Prasad V.V.D.N., Chanchal S., Bhargava S.K. (2015) Tri-reforming of methane for the production of syngas: Review on the process, catalysts and kinetic mechanism [online], in: Asia Pacific Confederation of Chemical Engineering Congress: APCChE, incorporating CHEMECA, Melbourne, Engineers Australia, pp. 128-136.

28 Bakhtyari A., Darvishi A., Rahimpour M.R. (2016) A heat exchanger reactor equipped with membranes to produce dimethyl ether from syngas and methyl formate and hydrogen from methanol, Int. J. Membrane Sci. Technol. 3, 64-84.

29 Nimkar S.C., Mewada R.K., Rosen M.A. (2017) Exergy and exergoeconomic analyses of thermally coupled reactors for methanol synthesis, Int. J. Hydrogen Energy 42, 47, 2811328127.

30 Farsi M., Fekri Lari M., Rahimpour M.R. (2019) Development of a green process for DME production based on the methane tri-reforming, J. Taiwan Inst. Chem. Eng. 106, 9-19. doi: 10.1016/j.jtice.2019.10.001.

31 Richardson J.T., Paripatyadar S.A. (1990) Carbon dioxide reforming of methane with supported rhodium, Appl. Catal. 61, 1, 293-309.

32 Choudhary V.R., Rajput A.M., Prabhakar B. (1994) NiO/ $\mathrm{CaO}$-catalyzed formation of syngas by coupled exothermic oxidative conversion and endothermic $\mathrm{CO}_{2}$ and steam reforming of methane, Angew. Chem. Int. Ed. 33, 20, 2104-2106.

33 Al-Fatesh A.S., Naeem M.A., Fakeeha A.H., Abasaeed A.E. (2014) Role of $\mathrm{La}_{2} \mathrm{O}_{3}$ as promoter and support in $\mathrm{Ni} / \gamma-\mathrm{Al}_{2} \mathrm{O}_{3}$ catalysts for dry reforming of methane, Chin. J. Chem. Eng. 22, 1, 28-37.

34 Chen L., Gangadharan P., Lou H.H. (2018) Sustainability assessment of combined steam and dry reforming versus trireforming of methane for syngas production, Asia-Pac. J. Chem. Eng. 13, 2, e2168.

35 Singha R.K., Shukla A., Yadav A., Adak S., Iqbal Z., Siddiqui N., Bal R. (2016) Energy efficient methane trireforming for synthesis gas production over highly coke resistant nanocrystalline $\mathrm{Ni}-\mathrm{ZrO}_{2}$ catalyst, Appl. Energy 178, 15, 110-125.

36 Cho W., Song T., Mitsos A., McKinnon J.T., Ko G.H., Tolsma J.E., Denholm D., Park T. (2009) Optimal design and operation of a natural gas tri-reforming reactor for DME synthesis, Catal. Today. 139, 4, 261-267.

37 Tsipouriari Vaso A., Verykios Xenophon E. (2001) Kinetic study of the catalytic reforming of methane with carbon dioxide to synthesis gas over $\mathrm{Ni} / \mathrm{La}_{2} \mathrm{O}_{3}$ catalyst, Catal. Today. 64, 1-2, 83-90.

38 Nandini A., Pant K.K., Dhingra S.C. (2006) Kinetic study of the catalytic carbon dioxide reforming of methane to synthesis gas over $\mathrm{Ni}-\mathrm{K} / \mathrm{CeO}_{2}-\mathrm{Al}_{2} \mathrm{O}_{3}$ catalyst, Appl. Catal. A. 308, 10, 119-127. 
39 Richardson J.T., Paripatyadar S.A. (1990) Carbon dioxide reforming of methane with supported rhodium, Appl. Catal. 61, 1, 293-309.

40 Minh D.P., Siang T.J., Vo D.V.N., Phan T.S., Ridart C., Nzihou A., Grouset D. (2018) Hydrogen production from biogas reforming: An overview of steam reforming, dry reforming, dual reforming, and tri-reforming of methane, in: Hydrogen supply chains, Academic Press, Cambridge, MA, pp. 111-166.

$41 \mathrm{Xu}$ J., Froment G.F. (1989) Methane steam reforming, methanation and water-gas shift: I. Intrinsic kinetics, AlChE J. 35, 1, 88-96.

42 Xiu G.H., Li P., Rodrigues A.E. (2002) Sorption-enhanced reaction process with reactive regeneration, Chem. Eng. Sci. $\mathbf{5 7}, \mathbf{1 8}, 3893-3908$.

43 Trimm D.L., Lam C.W. (1980) The combustion of methane on platinum - alumina fibre catalysts - I: Kinetics and mechanism, Chem. Eng. Sci. 35, 6, 1405-1413.

44 De Smet C., De Croon M., Berger R., Marin G., Schouten J. (2001) Design of adiabatic fixed-bed reactors for the partial oxidation of methane to synthesis gas. Application to production of methanol and hydrogen-for-fuel-cells, Chem. Eng. Sci. 56, 16, 4849-4861.
45 Gosiewski K., Bartmann U., Moszczynski M., Mleczko L. (1999) Efect of the intraparticle mass transport limitations on temperature profiles and catalytic performance of the reverse-flow reactor for the partial oxidation of methane to synthesis gas, Chem. Eng. Sci. 54, 20, 4589-4602.

46 Graaf G.H., Scholtens H., Stamhuis E.J., Beenackers A.A.C.M. (1990) Intra-particle diffusion limitations in lowpressure methanol synthesis, Chem. Eng. Sci. 45, 4, 773-783.

47 Barbieri G., Di Maio F.P. (1997) Simulation of the methane steam reforming process in a catalytic Pd-membrane reactor, Ind. Eng. Chem. Res. 6, 2121-2127.

48 Van Ness H., Smith J., Abbott M. (2001) Introduction to chemical engineering thermodynamics, McGraw-Hill, Crawfordsville.

49 Cussler E.L. (1997) Diffusion: Mass transfer in fluid systems, Cambridge University Press, Cambridge.

50 Reid R.C., Sherwood T.K., Prausnitz J. (1977) The properties of gases and liquids, 3rd edn., McGraw-Hill, New York.

51 Smith J.M. (1980) Chemical engineering kinetics, McGrawHill, New York. 